\title{
Relationships between surface and column aerosol radiative properties and air mass transport at a rural New England site
}

\author{
J. F. Slater ${ }^{1}$ and J. E. Dibb \\ Climate Change Research Center, Institute for the Study of Earth, Oceans, and Space, Earth Science Department, University \\ of New Hampshire, Durham, New Hampshire, USA
}

Received 13 January 2003; revised 16 August 2003; accepted 2 September 2003; published 9 January 2004.

[1] Chemical, physical, and radiative properties of surface and vertical column aerosols were measured at a rural site in southern New Hampshire from July 2000 to September 2001. The primary objective was to determine how intensive and extensive aerosol properties vary in air masses originating in different upwind regions. The data set also allows for an investigation of some of the relationships between surface and column aerosol properties at the site, and provides an estimate of direct radiative forcing by aerosols during the study period. Extensive properties (e.g., optical depth and chemical concentration) were at maximum values during times of south-southwest (S-SW) transport, while minimum values were seen during north-northeast (N-NE) transport. Certain intensive properties such as fine particle mass scattering efficiency did not vary significantly between times of transport from different source regions. Mean optical depth (wavelength $=500 \mathrm{~nm}$ ) was 0.24 during S-SW transport, compared to 0.10 during $\mathrm{N}-\mathrm{NE}$ transport. The study period average scattering efficiency for $\left(\mathrm{NH}_{4}\right)_{2} \mathrm{SO}_{4}$ was $6.54 \pm$ $0.26 \mathrm{~m}^{2} \mathrm{~g}^{-1}$ ( \pm standard error) and $3.36 \pm 0.49 \mathrm{~m}^{2} \mathrm{~g}^{-1}$ for organic carbon, while the absorption efficiency of elemental carbon was $12.85 \pm 0.80 \mathrm{~m}^{2} \mathrm{~g}^{-1}$. Top of the atmosphere aerosol direct radiative forcing was $-0.35 \pm 0.83 \mathrm{Wm}^{-2}$ ( \pm 1 standard deviation) in winter $2000-2001$ and $-9.06 \pm 3.77 \mathrm{Wm}^{-2}$ in summer 2001, differences that can be primarily attributed to seasonal changes in surface reflectance (high in winter, low in summer) and the relatively low values of single scatter albedo observed in winter. The annual average direct radiative forcing was $-5.14 \pm 4.32 \mathrm{Wm}^{-2}$. We generally observed a moderate correlation between surface and column aerosol light extinction, suggesting that vertical column aerosol radiative properties measured by surface-based radiometers should be supplemented by boundary layer measurements of aerosol chemical, physical, and radiative properties to help understand the mechanisms contributing to global aerosol variability. INDEX TERMS: 0305 Atmospheric Composition and Structure: Aerosols and particles (0345, 4801); 0365 Atmospheric Composition and Structure: Troposphere-composition and chemistry; 0368

Atmospheric Composition and Structure: Troposphere — constituent transport and chemistry; 3364

Meteorology and Atmospheric Dynamics: Synoptic-scale meteorology; KEYWORDS: aerosol transport, aerosol radiative forcing, rural New England

Citation: Slater, J. F., and J. E. Dibb (2004), Relationships between surface and column aerosol radiative properties and air mass transport at a rural New England site, J. Geophys. Res., 109, D01303, doi:10.1029/2003JD003406.

\section{Introduction}

[2] The scattering and absorption of short-wavelength solar radiation by atmospheric aerosol particles directly affects the radiative balance of the Earth. Recent model estimates of the direct industrial aerosol radiative forcing range between -0.07 and $-1.24 \mathrm{Wm}^{-2}$, compared to the estimated range of +2.19 to $+2.67 \mathrm{Wm}^{-2}$ due to the radiative forcing of anthropogenic greenhouse gases [IPCC, 2001]. One of the main causes of the large uncertainty associated

\footnotetext{
${ }^{1}$ Now at Division of Engineering, Mathematics, and Science, Daniel Webster College, Nashua, New Hampshire, USA.

Copyright 2004 by the American Geophysical Union. 0148-0227/04/2003JD003406\$09.00
}

with direct aerosol radiative forcing is variations in aerosol radiative, chemical, and physical properties in both time and space [Schwartz and Andreae, 1996; Charlson and Heintzenberg, 1995; Penner et al., 1994]. The eastern United States is one region on the Earth where direct anthropogenic aerosol radiative forcing is highly variable and typically exceeds that of anthropogenic greenhouse gases [e.g., Grant et al., 1999; Penner et al., 1998].

[3] Satellite platforms and global climate models are often used to map the variability of aerosol properties on regional to global scales [e.g., King et al., 1999; Liousse et al., 1993]. However, satellite algorithms and global climate models have to make assumptions concerning the relationship between aerosol properties measured at the surface and aerosol properties in the vertical column. In addition, 
satellite retrieval algorithms require assumptions about several key aerosol properties [Kaufman et al., 1997]. It is therefore necessary to measure column and surface aerosol radiative, physical, and chemical properties at regionally representative monitoring sites for long durations of time. This type of information can then be used to improve satellite aerosol retrieval algorithms, and to help validate global chemical-transport-radiation models that predict direct aerosol radiative forcing.

[4] Important wavelength dependent aerosol properties governing direct aerosol forcing include aerosol optical depth $\left(\tau_{\mathrm{a}}\right.$; the vertical integral of the light extinction coefficient), single scatter albedo ( $\omega$; the ratio of scattering to extinction), and the light scattering and absorption efficiencies of various chemical components $\left(\phi_{\mathrm{sp}}\right.$ and $\phi_{\mathrm{ap}}$; light scattered or absorbed per unit chemical mass) [Bergin et al., 2000; Charlson et al., 1999; Heintzenberg et al., 1997]. Aerosol optical depth is a variable often used to remotely assess aerosol concentrations in the atmosphere from surface-based instruments [e.g., Holben et al., 2001]. Direct radiative forcing is highly sensitive to small changes in single scatter albedo; the crossover between positive and negative forcing occurs at values of $\omega \sim 0.85$ (depending on surface albedo), with higher values yielding negative forcing [Heintzenberg et al., 1997; Chýlek and Coakley, 1974]. Light scattering and absorption efficiencies are the key parameters used to connect aerosol chemical and radiation models [Charlson et al., 1992], to assist in the interpretation of remotely sensed aerosol data [Tanré et al., 1997], and to reconstruct visibility reduction from aerosol chemical composition [Malm, 2000].

[5] In recent years, great strides have been made toward establishing aerosol variability through a global optical depth measurement network (AERONET [Holben et al., 2001]), and through regional networks such as the Canadian program AEROCAN [Bokoye et al., 1998] and the Swiss network CHARM [Ingold et al., 2001]. Surface aerosol chemical, physical, and optical properties have been characterized at baseline monitoring locations within the NOAA-CMDL global network [NOAA-CMDL, 2001, 1998], and by the IMPROVE network in rural areas throughout the United States [Sisler and Malm, 2000]. Equally important are results from intensive, multi-platform, short duration field campaigns focused on measuring and interpreting aerosol optical properties such as SCAR-B [Kaufman et al., 1998], TARFOX [Russell et al., 1999], ACE 1 [Bates et al., 1998], ACE-2 [Russell and Heintzenberg, 2000], and INDOEX [Ramanathan et al., 2001]. In addition, important advances in remote sensing of aerosol properties have been made that allow investigators to quantify regional changes of aerosol loadings [King et al., 1999]. From all of these efforts, a comprehensive global climatology of aerosol variability is emerging.

[6] In northeastern United States, a small network of radiometers has been making continuous measurements of $\tau_{\mathrm{a}}$ since 1991 [Michalsky et al., 1994]. Summers typically had the highest $\tau_{\mathrm{a}}$ and winters the lowest at sites in eastern Maine and eastern New York. Although sulfate aerosols are thought to be the dominant component responsible for column light extinction in the northeast, airborne measurements off the U.S. east coast indicated that carbonaceous aerosols can constitute $\sim 50 \%$ of the dry aerosol mass and were second only to water vapor in relative contribution to column light extinction [Novakov et al., 1997; Hegg et al., 1997]. In comparison, ground-based aerosol sampling results from the IMPROVE site in Acadia National Park, Maine, during 1988-1991 indicated that $\sim 50 \%$ of the fine aerosol mass consisted of ammonium sulfate and $\sim 35 \%$ of carbonaceous species. Light scattering by sulfate accounted for about two thirds of the surface light extinction budget [Malm et al., 1994].

[7] In the present work, we report on a 14-month long study of surface and column aerosol properties at a rural site in southern New Hampshire. Variations in aerosol properties are related to changes in air mass origin based on backward trajectory calculations. Specific objectives of this study are (1) establish seasonal patterns in air mass transport to the measurement site, (2) examine the seasonality of $\tau_{\mathrm{a}}$ and $\omega$, (3) estimate the influence variations in air mass origin have on surface and column aerosol properties, (4) establish the relationship between surface light extinction and column light extinction, and (5) estimate annual and seasonal direct aerosol radiative forcing.

\section{Methods}

\subsection{Sampling Site and $\mathbf{P M}_{2.5}$ Chemical, Physical, and Optical Measurements}

[8] The measurement site is located in a rural area of southern New Hampshire approximately $22 \mathrm{~km}$ inland from the Atlantic Ocean (Thompson Farm, $43.11^{\circ} \mathrm{N}, 70.95^{\circ} \mathrm{W}$; $21 \mathrm{~m}$ elevation). The sampling tower is located on a knoll in a meadow and is removed from substantial local sources of airborne pollutants and can thus be characterized as representative of a regional "background" aerosol. A lightly traveled paved road is less than $1 \mathrm{~km}$ to the south, a moderately traveled paved road is $5 \mathrm{~km}$ to the east, and Interstate 95 is $15 \mathrm{~km}$ eastward. Chemical, physical, and optical properties of $\mathrm{PM}_{2.5}$ (airborne particles with an aerodynamic diameter $\leq 2.5 \mu \mathrm{m}$ ) are measured at the site using a custom manufactured sampling device that delivers fine particles to three $47 \mathrm{~mm}$ diameter filter cartridges, a Particle Soot Absorption Photometer (PSAP, Radiance Research, Seattle, Washington), and an integrating nephelometer (M903, Radiance Research). The device is located on a platform $5 \mathrm{~m}$ above the ground. Temperature within the sampling device is kept slightly $\left(\sim 1^{\circ} \mathrm{C}\right)$ above the outside temperature to inhibit the condensation of water vapor. The inlet is a URG (University Research Glassware, RTP, NC) cyclone that has been characterized to have a $\mathrm{D}_{50} 2.5 \mu \mathrm{m}$ cut point at 93 liters per minute (Lpm) flow rate. Ambient air is split into the five channels with $28 \mathrm{Lpm}$ going to each of the three filter cartridges (teflon filter, quartz-fiber filter, and an optional cartridge) $7 \mathrm{Lpm}$ to the nephelometer, and $2 \mathrm{Lpm}$ to the photometer. The optional filter cartridge is used occasionally to collect filters for $\mathrm{PM}_{2.5}$ mass measurements.

[9] The teflon and quartz-fiber filters were collected every 24 hours (0700 to $0700 \mathrm{LT}$ ), and field blanks were obtained every 7 days, from 7 July to 15 December 2000 and from 15 February to 3 September 2001 (360 days). However, due to budget constraints only a subset of the filters was analyzed (detailed below). The teflon filters (FALP, Millipore, Bedford, MA) were extracted in Milli-Q water after being wetted with high purity methanol and then 
analyzed for eight inorganic ions $\left(\mathrm{Ca}^{2+}, \mathrm{Na}^{+}, \mathrm{Mg}^{2+}, \mathrm{K}^{+}, \mathrm{NH}_{4}^{+}\right.$, $\mathrm{Cl}^{-}, \mathrm{NO}_{3}^{-}$, and $\left.\mathrm{SO}_{4}^{2-}\right)$ and one organic ion $\left(\mathrm{C}_{2} \mathrm{O}_{4}^{2-}\right)$ in our laboratory at the University of New Hampshire by ion chromatography [cf. Jordan et al., 2000]. The limit of detection (LOD) is $0.02 \mu \mathrm{g} / \mathrm{m}^{3}$ for $\mathrm{NH}_{4}^{+}$, and $0.002 \mu \mathrm{g} / \mathrm{m}^{3}$ for $\mathrm{SO}_{4}^{2-}$, determined by three times the standard deviation of 54 field blanks collected at the site. The estimated relative precision (coefficient of variance of duplicate measurements) is $1.1 \%$ for $\mathrm{NH}_{4}^{+}$, and $0.6 \%$ for $\mathrm{SO}_{4}^{2-}$. Pre-weighed teflon filters were also collected for $\mathrm{PM}_{2.5}$ mass on a 1-in-3 day schedule during June-August 2001 (0700 to 0700 LT). Filter handling and weighing protocols followed the U.S. EPA's guidance for $\mathrm{PM}_{2.5}$ mass measurements. The filters were equilibrated at constant temperature $\left(20 \pm 2^{\circ} \mathrm{C}\right)$ and constant RH $(30 \pm 2 \%)$ for at least 24 hours prior to weighing before and after collection.

[10] The quartz filters (2500 QAT-UP, Pall Gelman, Ann Arbor, Michigan) were analyzed for elemental carbon (EC), organic carbon (OC), and total carbon (TC) using the thermal-optical/transmission method at Sunset Lab [Birch and Cary, 1996]. Since carbonaceous aerosols can consist of a large number of different compounds that contain $\mathrm{H}, \mathrm{O}$, and possibly hetero-atoms from a variety of natural and anthropogenic sources [e.g., Rogge et al., 1993], a conversion factor is needed to estimate the mass of OC from the mass of carbon quantified by the thermal-optical method. In this work, we have applied a conversion factor of 1.4 , as suggested by several authors [e.g., Gray et al., 1986; Wolff et al., 1981]. Additionally, both positive [e.g., Turpin et al., 1994] and negative [e.g., Eatough et al., 1999] sampling artifacts complicate quartz-fiber filter collection of OC. We chose to collect $\mathrm{OC}$ on a single filter and did not attempt to correct for any artifacts. Therefore, the reader should bear in mind that these possible artifacts may exist and should consider the $\mathrm{OC}$ values reported here as operationally defined. Based on the analysis of 54 field blanks and 23 sample duplicate measurements, the LOD for OC is $0.20 \mu \mathrm{g} / \mathrm{m}^{3}$ and the estimated precision is $2.2 \%$. The LOD for $\mathrm{EC}$ is $0.01 \mathrm{\mu g} / \mathrm{m}^{3}$ and the precision is $7.2 \%$.

[11] Light scattering coefficient $\left(\sigma_{\mathrm{sp}}\right)$ measurements by the nephelometer (wavelength $(\lambda)=530 \mathrm{~nm}$ ) were made at a low reference relative humidity $(\mathrm{RH} \leq 45 \%)$ to measure properties that are intrinsic to the aerosol and are mainly independent of atmospheric relative humidity. The nephelometer was calibrated with filtered air and filtered $\mathrm{CO}_{2(\mathrm{~g})}$ every 30 days. However, we did not correct the $\sigma_{\mathrm{sp}}$ measurements for nephelometer zero drift on a regular basis; instead we attempted to account for this source of error when calculating the combined standard uncertainty of $\sigma_{\mathrm{sp}}$. Other potential sources of error in the nephelometer output arise from nonidealities of the wavelength and angular sensitivities that can reduce the instrument's accuracy [Anderson et al., 1996]. On the basis of these potential sources of error we estimated that the combined standard uncertainty of the nephelometer measurements is $\pm 15 \%$.

[12] In contrast to the nephelometer, light absorption coefficient $\left(\sigma_{\mathrm{ap}}\right)$ measurements by the PSAP $(\lambda=565 \mathrm{~nm})$ cannot be routinely calibrated so the user relies on the manufacturer's calibration and the stable performance of the instrument over time. Bond et al. [1999] evaluated the performance of the PSAP and suggested various correction factors, which we have applied in the current work. These corrections include flow rate, scattering interferences, and a particle deposition spot size correction. We have also included the uncertainties associated with each correction factor as suggested by Bond et al. and have estimated that the combined standard uncertainty in $\sigma_{\text {ap }}$ is $\pm 18 \%$. In addition, the Bond et al. correction scheme implicitly adjusts the PSAP output to a wavelength of $550 \mathrm{~nm}$.

[13] The PSAP measurements were performed at ambient RH throughout the study. Recent work of Arnott et al. [2003] shows that the response of the PSAP can be erratic when RH is rapidly changed (over a period of less than 1 hour) from $40 \%$ to $90 \%$; however, it is not clear from the work of Arnott et al. what effect a gradual rise in $\mathrm{RH}$ would have on the PSAP measurements. At the Thompson Farm site on a typical summer day, the RH changes from $\sim 40 \%$ to $\sim 90 \%$ over an 8-10 hour period. Nonetheless, the reader should bear in mind the potential problems associated with PSAP measurements at high RH as outlined by Arnott et al. [2003].

[14] Because $\sigma_{\mathrm{sp}}$ and $\sigma_{\mathrm{ap}}$ are measured at different wavelengths, we have corrected $\sigma_{\mathrm{sp}}$ to the wavelength of the corrected PSAP readings $(\lambda=550 \mathrm{~nm})$ based on the power law $\sigma_{\mathrm{sp}} \propto \lambda^{-\alpha}$ which describes the wavelength dependence of scattered light. The exponent, $\alpha$, is referred to as the Angström exponent [Angström, 1929] and has been estimated to be $1.7 \pm 0.4$ at the Thompson Farm site based on daily averages of multi-spectral optical depth measurements. The scattering and absorption coefficients are used to calculate the particle light extinction coefficient at $550 \mathrm{~nm}\left(\sigma_{\mathrm{ep}}=\sigma_{\mathrm{sp} 550 \mathrm{~nm}}+\sigma_{\mathrm{ap}}\right)$, which in turn is used to calculate the single scatter albedo at $550 \mathrm{~nm}(\omega=$ $\left.\sigma_{\mathrm{sp} 550 \mathrm{~nm}} / \sigma_{\mathrm{ep}}\right)$. The combined standard uncertainty for $\sigma_{\mathrm{ep}}$ is $\pm 20 \%$, which results from a combination of the uncertainty in scattering and absorption measurements, as well as from the range in $\alpha$ of 1.3 to 2.1 . It is important to point out that due to differences in $\mathrm{RH}$ in the column and $\mathrm{RH}$ in our dried scattering measurements, using a vertical column Ångström exponent to adjust wavelengths likely introduced a systematic bias.

\subsection{Aerosol Optical Depth Measurements}

[15] Total and diffuse horizontal irradiance are measured at Thompson Farm using a multi-filter rotating shadowband radiometer (MFRSR) in six narrow bands, approximately $10 \mathrm{~nm}$ wide, centered on $415,500,615,673,870$, and $940 \mathrm{~nm}$ (Yankee Environmental Systems, Turners Fall, Massachusetts). Details of the instrument are given by Harrison et al. [1994]. Measurements are made every $15 \mathrm{~s}$ and one-minute averages are recorded. The MFRSR is heated to keep its components at a constant temperature, and to keep it free of snow and ice. From the measured total and diffuse components, direct normal irradiance is calculated, which is used in the calculation of aerosol optical depth $\left(\tau_{\mathrm{a}}\right)$ at $500 \mathrm{~nm}$ and $670 \mathrm{~nm}$.

[16] The key to successful AOD measurements is to develop a procedure that calibrates the instrument under stable atmospheric conditions on a semi-continuous basis. The Langley method of calibration has been used historically by many investigators [e.g., Shaw, 1983]. To begin, we express the Bouguer-Lambert-Beer law in instrument terms:

$$
\mathrm{V}=\mathrm{V}_{\mathrm{o}} \exp (-\tau m)
$$


where $\mathrm{V}$ and $\mathrm{V}_{\mathrm{o}}$ are the response of the MFRSR at the surface and at the top of the atmosphere, respectively, $\tau$ is the total column optical depth, and $m$ is the air mass traversed by the direct solar beam relative to the air mass in the zenith direction [Michalsky et al., 2001]. The $\mathrm{V}_{\mathrm{o}}$ term is continuously adjusted to account for variations in the sunearth distance. Calculations of solar air mass that consider the effects of the curvature of the earth and the refraction of an atmosphere of variable density on the trajectory of a solar beam are achieved through the equation:

$$
m=\left[\cos \theta_{\mathrm{z}}+0.15\left(93.885-\theta_{\mathrm{z}}\right)^{-1.253}\right]^{-1}
$$

where $\theta_{z}$ is the solar zenith angle [Kasten, 1966]. Taking the natural logarithm of both sides of equation (1), and rearranging, allows $\tau$ to be derived for each measurement of $\mathrm{V}$, given a calibrated $\mathrm{V}_{\mathrm{o}}$ value.

[17] We employ a strategy, detailed by Michalsky et al. [2001], to obtain $V_{o}$ values which involves using successful Langley plots from the site to determine the instrument calibration. Langley plots were constructed by plotting the air mass $(m)$ as a function of the natural log of the response of the MFRSR at the surface (V). A successful Langley plot is one where the relationship between $m$ and $\ln (\mathrm{V})$ is linear. Successful Langley plots using morning and/or afternoon data are selected using the objective algorithm developed by Harrison and Michalsky [1994]. Briefly, the algorithm calculates $\mathrm{V}_{\mathrm{o}}$ (and $\tau$ ) on cloud-free days over a solar air mass range of two to six. The next step in the calibration procedure involves processing the 20 nearest Langley-plotderived values for $V_{o}$ at each wavelength. The 20 sets of $V_{o}$ values are then reduced to 10 by selecting the inter-quartile range of the ratio of $V_{o}$ at $500 \mathrm{~nm}$ to $V_{o}$ at $670 \mathrm{~nm}$. The median of these 10 sets of $V_{o}$ values is then used to calculate $\tau$ for the period of time covered by the Langley plots. By using the median of several days, this procedure helps to reduce the likelihood of a poor estimate of $\mathrm{V}_{\mathrm{o}}$ that might occur on days when the Langley plot of $\ln (\mathrm{V})$ versus $m$ appears linear when, in fact, the optical depth is changing [Michalsky et al., 2001; Shaw, 1976]. We performed this procedure and derived $\mathrm{V}_{\mathrm{o}}$ values at the beginning and at the end of the study period, and these were then used to calculate $\tau$ at one-minute intervals throughout the experiment. This time series of $\tau$ was then manually screened for cloud contamination and hourly averages were calculated when there were at least 20 one-minute values in that hour. The cloud screening procedure involves first performing a least squares fit on the one-minute resolution optical depth time series over 20- minute time intervals. If the residuals are within a specified tolerance (0.02), then the data are accepted, if not, that 20 -minute block is rejected. Also, if the mean of the 20-minute block is greater than 1.0, it is rejected based on the presumption that uniform overcast skies were present (J. Michalsky, personal communication, 2002).

[18] After solving equation (1) for $\tau$ using $V_{o}$ values derived by this technique, we must correct for Rayleigh scattering optical depth and ozone optical depth. Rayleigh optical depth $\left(\tau_{\text {Ray }}\right)$ is calculated using the formula [Hansen and Travis, 1974]:

$$
\tau_{\text {Ray }}=0.008569 \lambda^{-4}\left(1+0.0113 \lambda^{-2}+0.00013 \lambda^{-4}\right) \mathrm{P} / \mathrm{P}_{\mathrm{o}},
$$

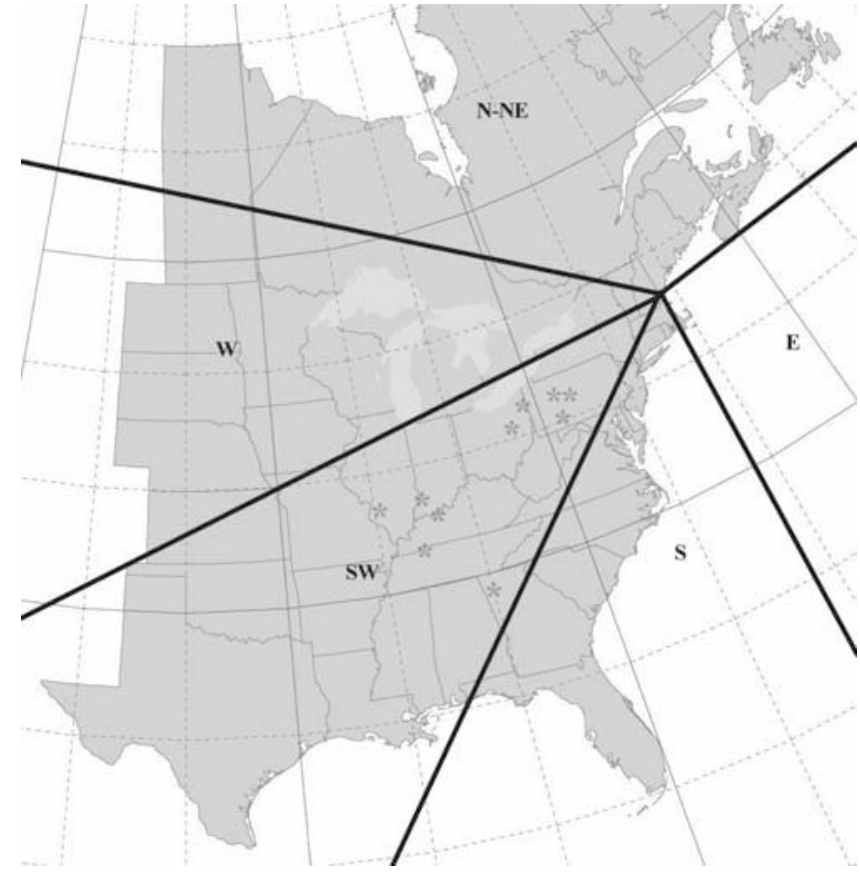

Figure 1. Study source regions used to categorize back trajectory origins: north-northeast (N-NE), east (E), south $(\mathrm{S})$, southwest (SW), and west $(\mathrm{W})$. The stars represent the location of the top $10 \mathrm{SO}_{2}$ emitting plants in the United States (U.S. EPA, AIR Data Base, 2001).

where $\mathrm{P}$ is the site pressure (hourly averages) relative to sea level pressure $\mathrm{P}_{\mathrm{o}}$ and $\lambda$ is in micrometers. Ozone optical depth is removed by multiplying daily average column ozone measurements obtained from NASA's Total Ozone Mapping Spectrometer http://toms.gsfc.nasa.gov/ ozone/ozone.html, 2001) by the Chappuis band ozone absorption coefficients obtained from a look-up table formula [Hansen and Travis, 1974]. Rayleigh and ozone optical depths are then subtracted from total optical depth, leaving $\tau_{\mathrm{a}}$. AOD uncertainty as measured by the MFRSR is estimated to be \pm 0.01 optical depths [cf. Michalsky et al., 2001].

[19] We have also derived the Angström Exponent $(\alpha)$ at one-minute resolution throughout the study period. This parameter can be used to infer the relative size distribution of the column-integrated aerosol. Angström [1929] proposed that extinction of solar radiation by aerosols is a continuous function of wavelength, without selective bands or lines for scattering or absorption. Thus the Ångström turbidity formula is given by

$$
\tau_{a}(\lambda)=\beta \lambda^{-\alpha},
$$

where $\beta$ is referred to as the turbidity coefficient and $\alpha$ was described above [Angström, 1929, 1930]. From the known power law $\tau \propto \lambda^{-\alpha}$, it is expected that $\alpha$ should vary from 4 to 0 ; when particles are very small $\alpha$ should approach 4 , and $\alpha$ should approach 0 for particles much larger than the wavelength of light. To calculate $\alpha$ we use the formula:

$$
\alpha=-\log \left(\tau_{\mathrm{a} 670} / \tau_{\mathrm{a} 500}\right) / \log (670 / 500),
$$



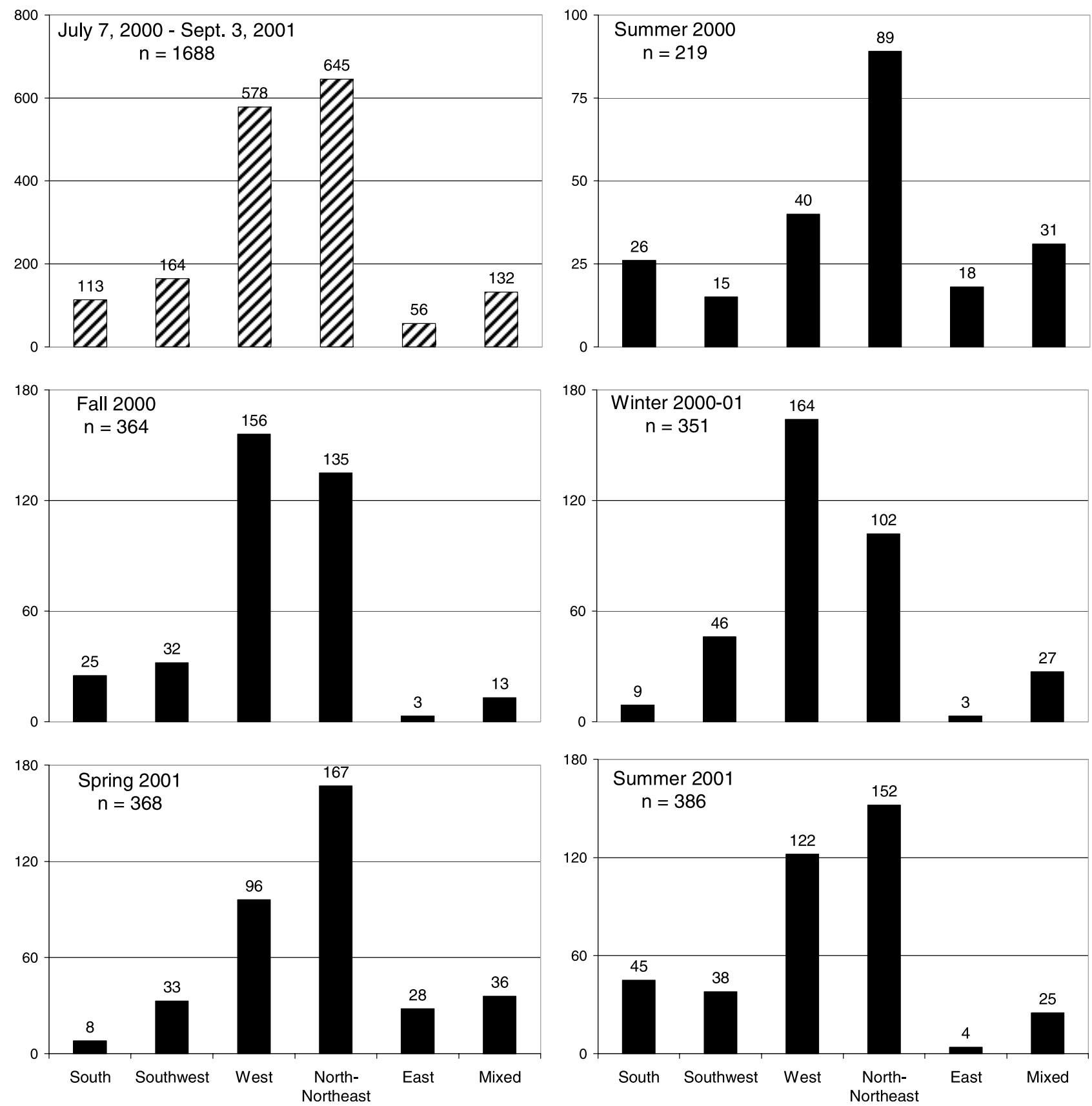

Figure 2. Annual and seasonal distribution of 3-day backward trajectories calculated every 6 hours at a starting height of $1000 \mathrm{~m}$. The source regions are shown in Figure 1. Mixed sources occurred when the trajectory passed over two or more source regions in route to the measurement site.

where $\tau_{\mathrm{a}} 670$ and $\tau_{\mathrm{a}} 500$ are the aerosol optical depths at $670 \mathrm{~nm}$ and $500 \mathrm{~nm}$, respectively.

\subsection{Fine Particle Scattering and Absorption Efficiencies}

[20] Specific light scattering and absorption efficiencies were calculated to connect the scattering and absorption of light by fine particles and the chemical composition of those particles. Light absorption efficiency is typically assumed to depend only on the presence of EC; therefore, absorption efficiency is defined as the incremental change in $\sigma_{\text {ap }}$ per unit changes in EC mass (per volume of air) and is determined by simple linear regression. Light scattering efficiency, on the other hand, needs to be derived for each chemical species present that contributes to scattering [e.g., Sloane, 1986]. Thus light scattering efficiencies $(\lambda=$ $530 \mathrm{~nm}$ ) are the proportionality constants that are estimated by multivariate regression analysis such that

$$
\sigma_{\mathrm{sp}}=\sum_{i} \mathrm{a}_{i} \mathrm{M}_{i}
$$

where $\mathrm{M}_{i}$ represents the fine particle mass of chemical specie $i$ per volume of air and $\mathrm{a}_{i}$ is the fitting constant that is interpreted as the light scattering efficiency of chemical 
a)
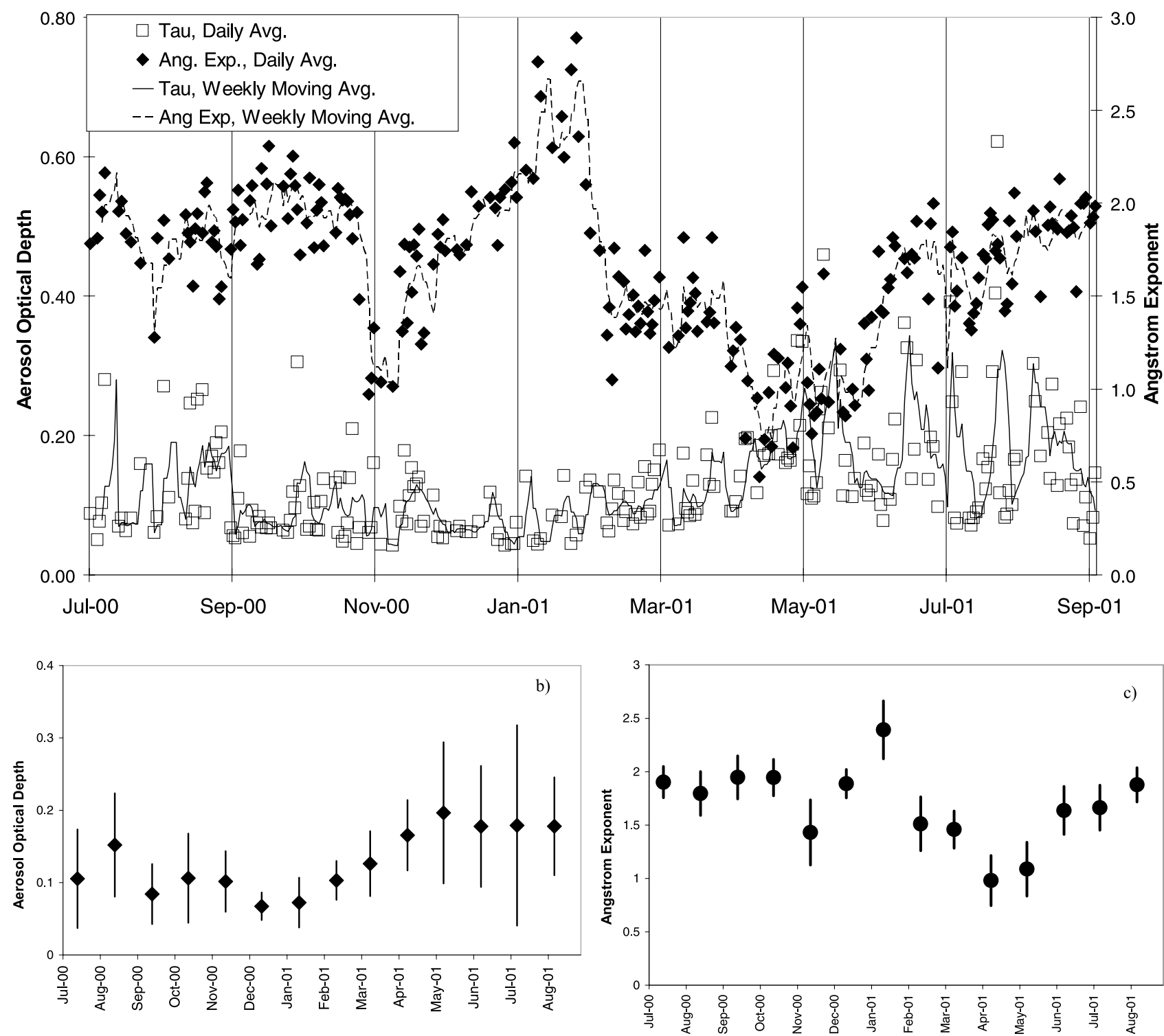

Figure 3. (a) Daily averages $(n=241)$ and running weekly mean of aerosol optical depth (Tau) at $\lambda=$ $500 \mathrm{~nm}$ and Ångström Exponent (Ang. Exp.). (b and c) Monthly averages of aerosol optical depth (Figure 3b) and Angstrom Exponent (Figure 3c). Error bars equal \pm 1 standard deviation.

species $i$ [Sloane, 1986; Ouimette and Flagan, 1982; White and Roberts, 1977]. Equation (6) assumes that the aerosol is externally mixed (discrete particles of one chemical composition). Although White [1986] demonstrated that the chemical apportionment of the light extinction budget could not be treated identically for an external versus an internal mixture (particles of two or more chemical components), recent theoretical work by Malm and Kreidenweis [1997] showed that scattering efficiencies of mixtures of organic carbon and sulfates were insensitive to the choice of internal or external mixtures.

\subsection{Aerosol Radiative Forcing Calculations}

[21] Daily average direct clear-sky aerosol radiative forcing $(\Delta \mathrm{F})$ can be estimated using the equation [Chýlek and Wong, 1995; Haywood and Shine, 1995]

$$
\Delta \mathrm{F}=-\mathrm{DS}_{\mathrm{o}} \mathrm{T}_{\mathrm{at}}^{2} \omega \beta \tau_{\mathrm{a}}\left[\left(1-\mathrm{R}_{\mathrm{s}}\right)^{2}-\left(2 \mathrm{R}_{\mathrm{s}} / \beta\right)(1 / \omega-1)\right]
$$

where $\mathrm{D}$ is the fractional day length (variable throughout year), $\mathrm{S}_{\mathrm{o}}$ is the Solar Constant $\left(1370 \mathrm{~W} \mathrm{~m}^{-2}\right), \mathrm{T}_{\mathrm{at}}$ is the atmospheric transmission above the aerosol layer, $\omega$ is the single scatter albedo (the ratio of scattering to extinction), $\beta$ is the aerosol hemispheric upscatter fraction, and $\mathrm{R}_{\mathrm{s}}$ represents the surface reflectance (albedo). In equation (7), $\beta$ is averaged over solar zenith angles and $\mathrm{T}_{\mathrm{at}}=0.76$, as suggested by Haywood and Shine [1995]. It is important to note that because we made $\sigma_{\text {sp }}$ measurements at a low controlled RH $(\leq 45 \%)$, that we are unable to account for variations in $\mathrm{RH}$ in the vertical column; during days when the RH diurnal cycle is large (mainly in the summer months), this could have a significant impact on the radiative forcing calculations. 
[22] We have derived $R_{s}$ values from the Moderate Resolution Imaging Spectrometer (MODIS) BRDF/Albedo Product (MOD43B). The MODIS instrument flies on board NASA's Terra satellite and provides near global coverage on a daily basis [King et al., 1992]. The albedo product is produced at $1 \mathrm{~km}$ resolution by aggregating all available cloud-cleared and atmospherically corrected surface reflectance observations over 16-day intervals [Lucht et al., 2000].

[23] To derive $\beta$, many investigators use the ratio of the hemispheric backscatter coefficient to $\sigma_{\mathrm{sp}}(b)$ measured with a nephelometer equipped with a backscatter shutter [e.g., Delene and Ogren, 2001; Anderson et al., 1999]. However, because the M903 nephelometer does not measure backscatter, we have used a range of literature values of $b$ from mid-latitude continental sites in the United States [Delene and Ogren, 2001; Koloutsou-Vakakis et al., 2001]. It was shown by these investigators that $b$ does not significantly vary in either time or space. For the current work we have selected a range of $b$ from 0.10 to 0.13 . To calculate $\beta$, we use the equation $\beta=0.0817+1.85 b-2.97 b^{2}$ from Sheridan and Ogren [1999], who extracted the equation from the work of Wiscombe and Grams [1976]. Using a range of values for $b$ introduces upper and lower limits for $\beta$ ( 0.24 to 0.27$)$, which we have incorporated into the calculation of $\Delta \mathrm{F}$ uncertainty.

\subsection{Backward Trajectory Model, Source Regions, and Filter Selection Process}

[24] Three-day three-dimensional back trajectories have been calculated using the NOAA HYSPLIT 4 Model (Hybrid Single-Particle Lagrangian Integrated Trajectory Model [Draxler and Hess, 1997]). For this work, the model was driven by $80 \mathrm{~km} \times 80 \mathrm{~km}$ grid meteorological fields (at 22 vertical layers) produced by the Eta Data Assimilation System available from the NOAA-ARL Ready web site http://www.arl.noaa.gov/ready/, 2001). The trajectories had a starting height of $1000 \mathrm{~m}$ above model terrain height and were calculated every six hours from 7 July 2000 to 3 September 2001. A starting height of $1000 \mathrm{~m}$ above model terrain height was chosen based on the premise that this height is approximately the annual average of the middle of the mixed layer at this site. A higher level may be in the free troposphere during certain times of the year; if a lower level was chosen the modeled flow could be affected by surface friction.

[25] Each trajectory was manually classified into one of five source regions, or classified as "mixed" when the trajectory passed through more than one region on its way to our measurement site (Figure 1). We attempted to delineate source regions such that N-NE (north-northeast) represents clean continental air advecting out of Canada, W (west) represents air that has been impacted by industrial and urban complexes in southern Canada and the Great Lakes region, SW (southwest) represents air influenced primarily by emissions from coal-fired power plants in the Ohio River Valley and beyond, S (south) represents air impacted by transportation and urban sources on the Atlantic seaboard, and E (east) represent clean maritime air.

[26] We are able to describe the influence of air mass type on the physical, chemical, and optical properties of column and surface aerosols at the measurement site by partitioning trajectories into specific source regions. An air mass (not to be confused with solar air mass mentioned above) is considered to be a large homogenous volume of air characterized by a specific vertical profile of various state parameters (e.g., RH and temperature). Logically, the properties of aerosols are also thought to be uniform within an air mass at any given moment in time. Combining this generalization with information from back trajectories does not, of course, consider the history of an air mass further back in time than the specified trajectory duration (3 days).

[27] We used this air mass history information to select 24-hour integrated filters for chemical analysis. Even though we collected quartz and teflon $\mathrm{PM}_{2.5}$ filters every day during the 2 periods mentioned above, only a portion were analyzed for soluble ions and carbon. To select filters for analysis, the four trajectories that coincided with the 24-hour filter time interval had to all come from one of the source regions shown in Figure 1. This screening process led to $43 \%$ of the filters being analyzed (155 out of 360 ). Chemical analysis results, along with 24-hour averages of $\sigma_{\mathrm{sp}}$ and $\sigma_{\mathrm{ap}}$, were used to derive $\left(\mathrm{NH}_{4}\right)_{2} \mathrm{SO}_{4}$ and $\mathrm{OC}$ scattering efficiencies, and EC absorption efficiencies, for the different air mass types. However, because of a low number of cases when transport was consistently out of the SW or S over the 24-hour filter period, we combined these two regions when calculating scattering and absorption efficiencies.

\section{Results and Discussion}

\subsection{Distribution of Trajectories Into Source Regions}

[28] A total of 1688 trajectories were calculated during the study period. Roughly $38 \%$ had 3 -day origins in the north-northeast region, while $34 \%$ originated in the west. In comparison, $10 \%$ originated in the southwest region, $7 \%$ in the south region, $8 \%$ were from mixed sources, and just $3 \%$ originated in the east (Figure 2). A seasonal breakdown indicates a similar distribution during most of the seasons. During each season from September 2000 to September 2001 at least $71 \%$ of the trajectories originated in the west or north-northeast regions. In comparison, transport from the south and southwest ranged from a low of $11 \%$ during spring 2001 to a high of $22 \%$ during summer 2001. Transport from the south occurred less than $5 \%$ of the time during fall 2000, winter 2000-2001, and in spring 2001, compared to $12 \%$ of the time during summer 2001 and summer 2000 (Figure 2).

\subsection{Seasonality of Aerosol Surface and Column Optical Properties}

[29] Hourly values of $\tau_{\mathrm{a}}$ (wavelength $=500 \mathrm{~nm}$ ) and $\alpha$ were used to calculate daily averages throughout the study period. We were able to derive $\tau_{\mathrm{a}}$ on 241 days out of 422 possible days (57\%). Typically, $4-8$ hourly averages were used for each daily average calculation; however, on 12 days, only one hourly value was available for the daily average. A high amount of variability in $\tau_{\mathrm{a}}$ is seen in the time series of daily and monthly averages, particularly in summer 2001 (Figures 3a and 3b). The highest daily average of $\tau_{\mathrm{a}}(0.621)$ was recorded on 24 July 2001. Turbidity then dropped rapidly over the next 24 hours to a below average $\tau_{\mathrm{a}}$ value of 0.112 on $25 \mathrm{July}$. The lowest 

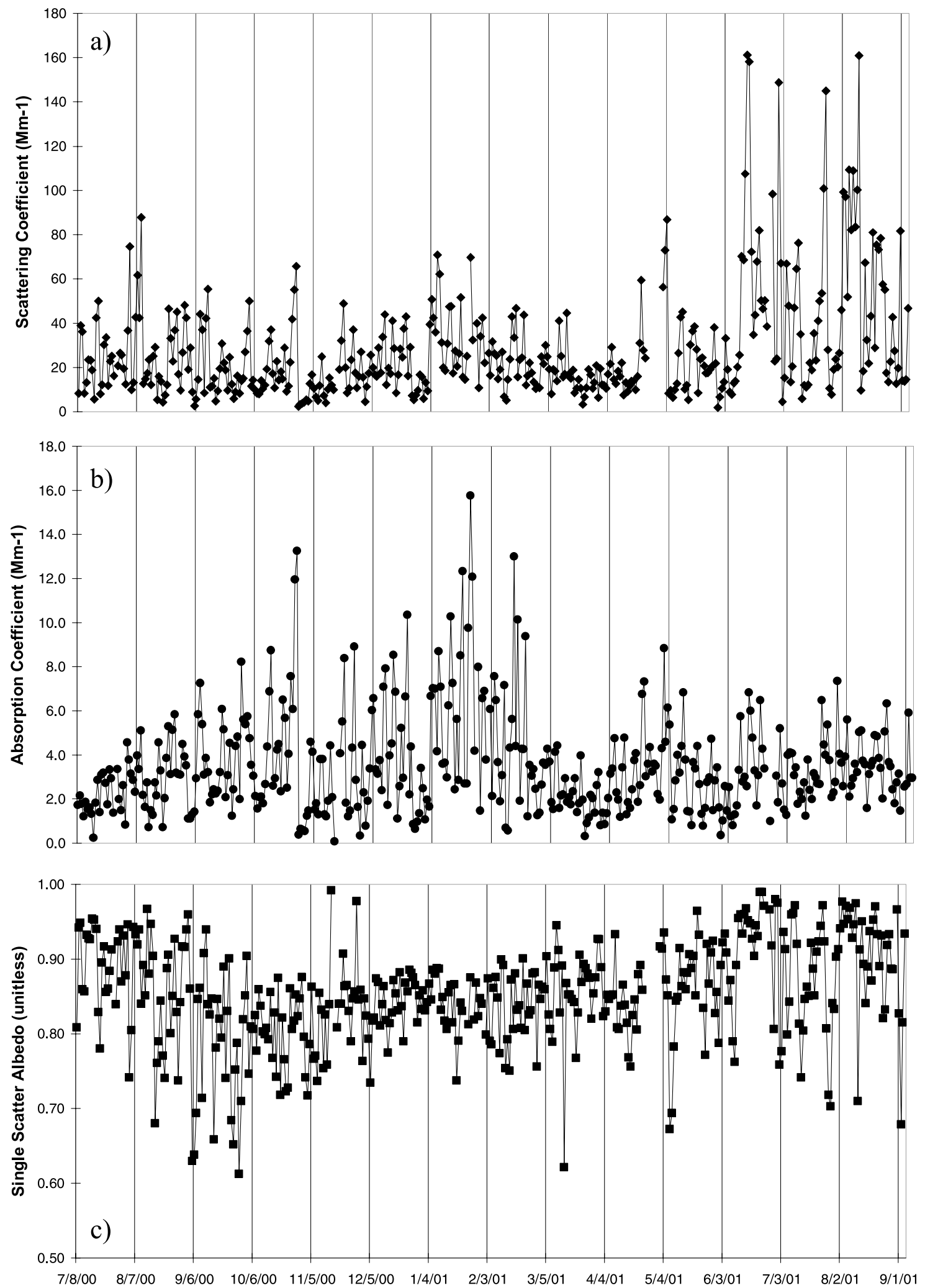

Figure 4. Time series of $\mathrm{PM}_{2.5}$ daily average (a) scattering coefficient $(\lambda=530 \mathrm{~nm})$, (b) absorption coefficient $(\lambda=550 \mathrm{~nm})$, and (c) single scatter albedo $(\lambda=550 \mathrm{~nm})$ for the entire study period of 7 July 2000 to 3 September 2001. 

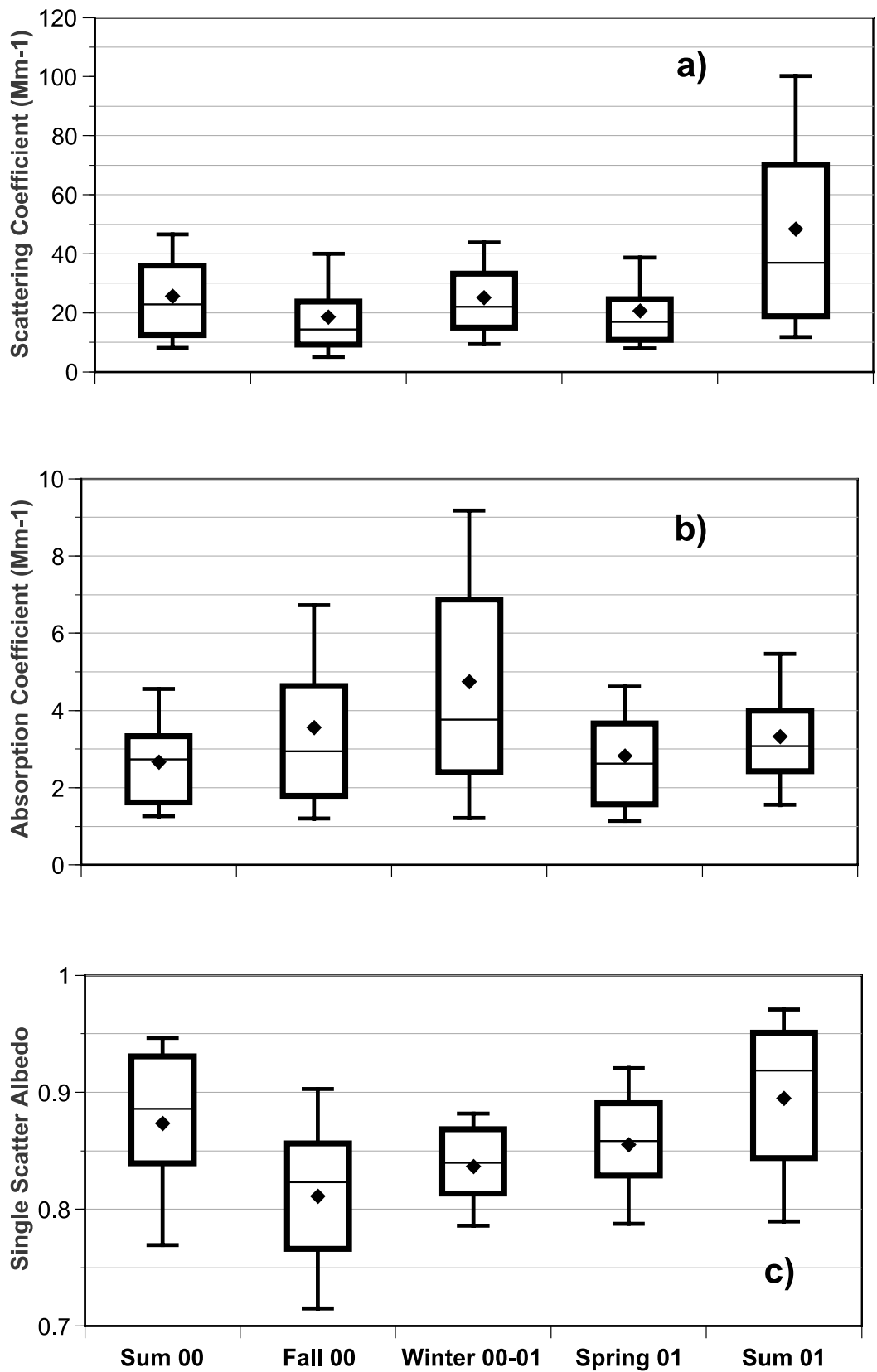

Figure 5. Seasonal distribution of (a) scattering coefficient, (b) absorption coefficient, and (c) single scatter albedo. The top and bottom of error bars are the 90th and 10th percentiles, the top and bottom of the box are the 75 th and 25 th percentiles, the line in the box is the median, and the symbol is the mean.

daily average $\alpha(0.527)$ was seen on 15 April 2001, and the highest values appear in winter. The time series of monthly average $\alpha$ (Figure $3 \mathrm{c}$ ) indicates that the springtime mean column-integrated particle size shifts to a slightly larger size distribution, which could be a reflection of an increase in atmospheric mineral dust that is typically observed in the free troposphere during spring [e.g., Dentener et al., 1996]. A much lower amount of variability in the monthly averages of $\alpha$ is seen than in monthly averages of $\tau_{\mathrm{a}}$ (illustrated by error bars in Figures $3 b$ and $3 c$ ).

[30] Monthly average values of $\tau_{\mathrm{a}}$ demonstrate that turbidity reaches its minimum in the winter and maximum in the summer (Figure 3b). Similar results have been shown by other investigations at continental sites in the United States [Holben et al., 2001; Michalsky et al., 1994] and in Canada [Smirnov et al., 1994]. At our measurement site, this annual cycle is probably influenced by increases in light scattering as RH increases in summer. Many investigators have documented the ability of atmospheric aerosols to absorb water, which significantly increase the particle's extinction cross section [e.g., Malm and Day, 2001; Hegg, 1993]. Changes in transport could also be influencing the aerosol burden between the two seasons through the delivery of more polluted air masses from the south and southwest; however, we have observed only subtle difference in our trajectory analysis. Backward trajectories cal- 
culated during winter 2000-2001 and summer 2001 reveal that both seasons had $>70 \%$ of their trajectories originating in the west or the north-northeast regions, while during summer 2001, 22\% of the trajectories originated in the south or southwest regions, compared to $16 \%$ in winter 2001-2001 (Figure 2).

[31] The daily average time series of $\mathrm{PM}_{2.5}$ surface light scattering coefficient $\left(\sigma_{\mathrm{sp}}\right)$ shows maximum values and large variability during summer 2001 compared to the rest of the study period (Figure 4a). Box and whisker plots of seasonal means and percentiles illustrate that scattering was fairly consistent from the beginning of our study period through spring of 2001 with seasonal averages of $\sigma_{\text {sp }}$ at or near $\sim 20 \mathrm{Mm}^{-1}$. During summer 2001, however, the mean rose to $\sim 50 \mathrm{Mm}^{-1}$ with the 90 th percentile reaching a value of $100 \mathrm{Mm}^{-1}$ (Figure 5a). In contrast to $\sigma_{\mathrm{sp}}, \mathrm{PM}_{2.5}$ surface light absorption coefficient $\left(\sigma_{\mathrm{ap}}\right)$ measurements display maximum values in winter, with considerable day-to-day variability (Figure 4b). Box and whisker plots show that winter 2000-2001 mean values of $\sigma_{\text {ap }}$ were near $5 \mathrm{Mm}^{-1}$, while the other season's values were $\sim 3 \mathrm{Mm}^{-1}$ with a smaller range (Figure 5b). These patterns in $\sigma_{\text {sp }}$ and $\sigma_{\text {ap }}$ led to a seasonal mean single scatter albedo $(\omega)$ minimum of 0.82 in fall 2000 and a $\omega$ maximum of 0.90 in summer 2001 (Figure 5c). A similar annual pattern in $\omega$ has been observed at the NOAA-CMDL regional monitoring site at Bondville, Illinois during 1996-1999, where the lowest monthly median values of $\omega(\sim 0.86)$ were observed in September and October [Delene and Ogren, 2001]. Our annual average $( \pm 1 \sigma)$ during September 2000 to September 2001 was $\omega=$ $0.86 \pm 0.07$, compared to the annual average during 19961999 at the Bondville site of $0.92 \pm 0.06$.

\subsection{Relationships Between Surface Aerosol Properties and Source Regions}

[32] Relationships between variations in air mass source regions, as indicated by back trajectories, and variations in $\sigma_{\mathrm{sp}}, \sigma_{\mathrm{ap}}$, and $\omega$ are investigated by comparing hourly averages of these parameters at the same time interval that a given trajectory is specified to arrive at the sampling site throughout the study period. Statistics for the hourly averages of each parameter are calculated once the individual trajectory and its associated $\sigma_{\mathrm{sp}}, \sigma_{\mathrm{ap}}$, and $\omega$ values have been classified into one of the source regions in Figure 1 (Table 1). As anticipated, the highest mean of $\sigma_{\text {sp }}$ and $\sigma_{\text {ap }}$ occurs when transport is from the southwest. The lowest mean $\sigma_{\mathrm{sp}}$ occurs during north-northeast transport and the lowest $\sigma_{\text {ap }}$ occurs when transport is out of the east (though there were few occurrences of easterly transport). The dominance of light scattering when transport is from the more polluted regions is illustrated by comparing $\omega$ values. The lowest $\omega$ occurs during north-northeast transport scenarios, and the highest occurs when transport is from the south (Table 1).

[33] The fact that the lowest $\omega$ values are observed during times when transport is from the cleanest sector suggests that elemental carbon (EC; the primary absorber in the atmosphere) is a ubiquitous and fairly constant component of aerosols in the eastern part of North America. EC is produced exclusively by combustion processes and, unlike the major light scattering components of aerosols (i.e., OC and $\mathrm{SO}_{4}^{2-}$ ), is a primary aerosol with a relatively long atmospheric lifetime [Goldberg, 1985]. Calculated lifetimes
Table 1. Relationships Between Variations in Air Mass Source Regions and Surface Fine Particle Optical Parameters ${ }^{\mathrm{a}}$

\begin{tabular}{|c|c|c|c|}
\hline & $\sigma_{\mathrm{sp}}$ & $\sigma_{\mathrm{ap}}$ & $\omega$ \\
\hline \multicolumn{4}{|c|}{$N-N E$} \\
\hline mean & 15.8 & 2.8 & 0.84 \\
\hline $\mathrm{SD}^{\mathrm{b}}$ & 15.1 & 2.7 & 0.08 \\
\hline $\max$ & 172 & 30.4 & 1 \\
\hline $\min$ & 0.6 & 0.1 & 0.48 \\
\hline $\mathrm{n}$ & 618 & 634 & 613 \\
\hline \multicolumn{4}{|c|}{ West } \\
\hline mean & 34.3 & 4 & 0.88 \\
\hline SD & 32.4 & 3.4 & 0.08 \\
\hline $\max$ & 218.3 & 25.3 & 1 \\
\hline $\min$ & 1.7 & 0.1 & 0.6 \\
\hline $\mathrm{n}$ & 545 & 556 & 534 \\
\hline \multicolumn{4}{|c|}{ Southwest } \\
\hline mean & 50.2 & 5.5 & 0.89 \\
\hline SD & 37.3 & 4.4 & 0.08 \\
\hline $\max$ & 244.3 & 35.5 & 1 \\
\hline $\min$ & 2.3 & 0.1 & 0.59 \\
\hline $\mathrm{n}$ & 158 & 160 & 157 \\
\hline \multicolumn{4}{|c|}{ South } \\
\hline mean & 41.1 & 3 & 0.92 \\
\hline SD & 35.8 & 2.8 & 0.06 \\
\hline $\max$ & 180.4 & 16 & 1 \\
\hline $\min$ & 3.9 & 0.04 & 0.7 \\
\hline $\mathrm{n}$ & 109 & 99 & 98 \\
\hline \multicolumn{4}{|c|}{$E-S E$} \\
\hline mean & 17.3 & 1.7 & 0.91 \\
\hline SD & 9.4 & 2.1 & 0.06 \\
\hline $\max$ & 39 & 11.6 & 1 \\
\hline $\min$ & 1.2 & 0 & 0.69 \\
\hline $\mathrm{n}$ & 51 & 50 & 50 \\
\hline
\end{tabular}

${ }^{\text {a }}$ Source regions determined by 3-day backward trajectories calculated every 6 hours from 7 July 2000 to 3 September 2001, and classified into the geographic regions illustrated in Figure 1. Optical parameters based on hourly values (at each 6 hour interval) of parameters $\left(\sigma_{\mathrm{sp}}\left(\mathrm{Mm}^{-1}\right)\right.$, scattering coefficient $(530 \mathrm{~nm}) ; \sigma_{\mathrm{ap}}\left(\mathrm{Mm}^{-1}\right)$, absorption coefficient $(550 \mathrm{~nm}) ; \omega$, single scatter albedo $\left(\sigma_{\mathrm{sp}} / \sigma_{\mathrm{sp}}+\sigma_{\mathrm{ap}}\right)$ at $\left.550 \mathrm{~nm}\right)$.

${ }^{\mathrm{b}} \mathrm{SD}$, standard deviation.

range from under 40 hours in rainy climates to well over 1 week in clean, dry regions [Ogren and Charlson, 1983]. There is little difference between EC concentrations when transport is from the north-northeast compared to transport from the more polluted sectors (south and southwest) (Figure 6). In contrast, $\mathrm{SO}_{4}^{2-}$ concentrations were roughly fivefold higher during south and southwest transport compared to north-northeast transport. A similar pattern is observed for $\mathrm{NH}_{4}^{+}$, while $\mathrm{OC}$ concentrations more closely resemble the variations seen in EC. Given the many different natural and anthropogenic sources of OC [e.g., Schauer et al., 1996], it is not surprising that one source region does not stand out in Figure $6 \mathrm{c}$. Thus it is apparent that the major differences between $\omega$ when transport is from the various source regions are governed primarily by changes in $\mathrm{SO}_{4}^{2-}$ source strength.

\subsection{Variations in Column Aerosol Properties and Source Regions}

[34] As shown above, we were able to extract hourly averages of the surface optical parameters for each trajectory that was calculated (because of continuous measurements). Vertical column optical parameters, however, are 

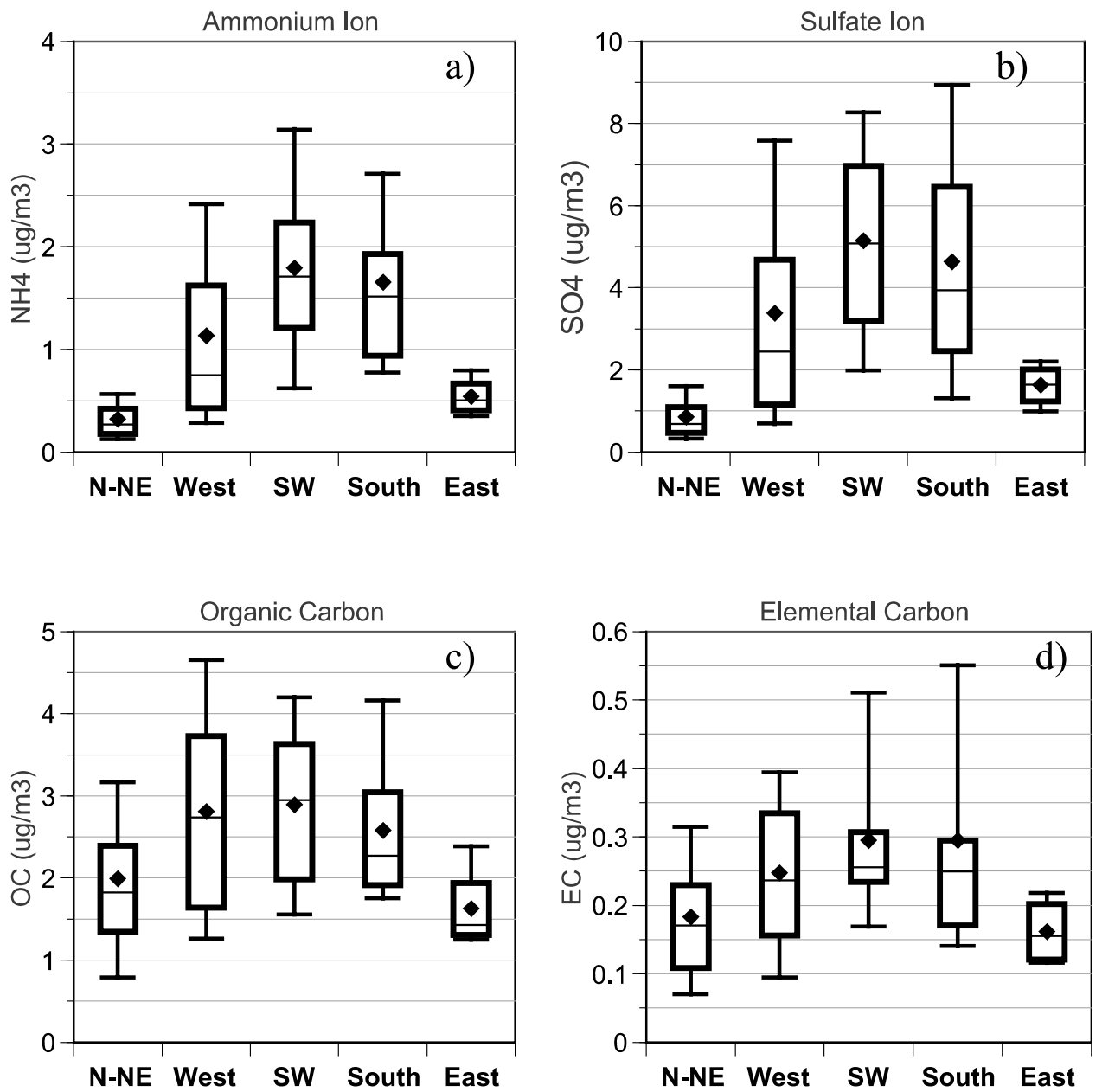

Figure 6. $\mathrm{PM}_{2.5}$ 24-hour integrated chemical composition broken down into the source regions shown in Figure 1 (see text). Number of filters analyzed per source region is N-NE (64), West (64), SW (11), South (12), and East (4). Bars, box, and symbols are same as in Figure 5.

limited to daylight hours when a clear path to the sun exists. As a result, there are many fewer hourly averages of column measurements with the same time-stamp as the trajectories (calculated every 6 hours). To increase the number of observations in each bin, we have grouped the south and southwest trajectories together when comparing transport patterns to column aerosol optical properties. Although the number of observations was relatively low for southwest transport $(\mathrm{n}=28)$ and south transport $(\mathrm{n}=14)$, the column optical parameters were not statistically different between the two transport scenarios. Thus we did not bias the results when combining measurements of air mass properties from the two source regions. In addition, there were only 2 observations when transport from the east and the trajectory calculation coincided, therefore we have disregarded these cases for this analysis.

[35] Similar to what was seen for $\mathrm{PM}_{2.5} \sigma_{\mathrm{sp}}$ at the surface, the highest $\tau_{\mathrm{a}}$ values were observed during south-southwest transport situations, mid-range values during westerly transport, and the lowest $\tau_{\mathrm{a}}$ during north-northeast transport (Table 2). Minimum and maximum $\tau_{\mathrm{a}}$ also follow this pattern. A student's t-test revealed that the differences between the mean values of $\tau_{\mathrm{a}}$ for south-southwest, west, and north-northeast air are statistically significant at the
Table 2. Relationships Between Variations in Air Mass Source Regions and Aerosol Column Optical Parameters ${ }^{\mathrm{a}}$

\begin{tabular}{|c|c|c|c|}
\hline & $\tau_{500}$ & $\tau_{670}$ & $\alpha$ \\
\hline \multicolumn{4}{|c|}{$N-N E$} \\
\hline mean & 0.10 & 0.06 & 1.6 \\
\hline $\mathrm{SD}^{\mathrm{b}}$ & 0.05 & 0.03 & 0.5 \\
\hline $\max$ & 0.29 & 0.19 & 3.3 \\
\hline $\min$ & 0.03 & 0.01 & 0.4 \\
\hline $\mathrm{n}$ & 141 & 141 & 141 \\
\hline \multicolumn{4}{|c|}{ West } \\
\hline mean & 0.14 & 0.09 & 1.7 \\
\hline $\mathrm{SD}$ & 0.08 & 0.05 & 0.4 \\
\hline $\max$ & 0.42 & 0.24 & 3.2 \\
\hline $\min$ & 0.05 & 0.02 & 0.6 \\
\hline $\mathrm{n}$ & 103 & 103 & 103 \\
\hline \multicolumn{4}{|c|}{$S-S W$} \\
\hline mean & 0.24 & 0.15 & 1.7 \\
\hline $\mathrm{SD}$ & 0.14 & 0.09 & 0.4 \\
\hline $\max$ & 0.71 & 0.41 & 2.7 \\
\hline $\min$ & 0.06 & 0.03 & 0.8 \\
\hline $\mathrm{n}$ & 42 & 42 & 42 \\
\hline
\end{tabular}

${ }^{\text {a }}$ Source regions determined by 3 -day backward trajectories calculated every 6 hours from 7 July 2000 to 3 September 2001, and classified into the geographic regions illustrated in Figure 1. Optical parameters based on hourly values (at each 6 hour interval) of parameters $\left(\tau_{500}\right.$ and $\tau_{670}=$ aerosol optical depth at $500 \mathrm{~nm}$ and $670 \mathrm{~nm} ; \alpha=$ Ångström Exponent).

${ }^{\mathrm{b}} \mathrm{SD}$, standard deviation. 

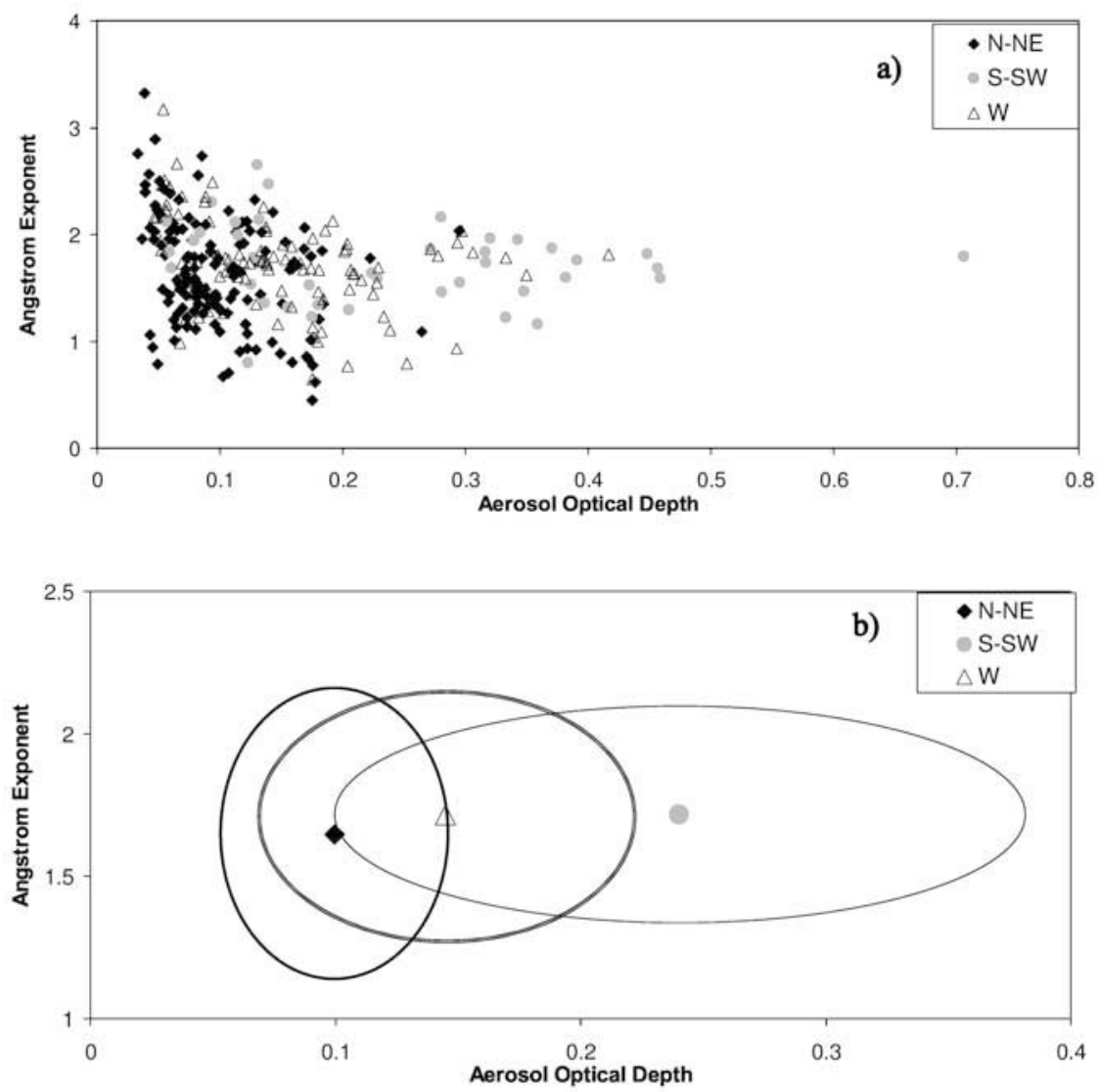

Figure 7. (a) Scatterplot of Ångström Exponent versus aerosol optical depth for the three air mass types. (b) Thresholds of one standard deviation about the mean help define the optical characteristics of each air mass type.

99\% level. In contrast, the differences between $\alpha$ for the different source regions are not statistically different (Table 2). This result is somewhat surprising, given the different aerosol formation mechanisms (and implied size distribution differences) that are likely taking place in the different source regions.

[36] There are slight differences in the range of $\alpha$ values between the three major source regions, even though the mean values of $\alpha$ are not significantly different. A scatter plot of $\alpha$ versus $\tau_{\mathrm{a}}$ is a standard optical representation that allows us to define physically interpretable patterns for the three air mass types [Smirnov et al., 1994; Ahern et al., 1991]. A slight decrease in $\alpha$ variability with increasing $\tau_{\mathrm{a}}$ is seen (Figure 7a). We have placed thresholds of one standard deviation about the mean to better optically characterize each air mass type and the result is shown in Figure 7b [cf. Smirnov et al., 1994]. This information can be used to place upper and lower limits on a priori optical characteristics of different air mass types for use in satellite retrieval algorithms and global climate models.

\subsection{Connections Between Surface and Column Aerosol Optical Properties}

[37] In the past, estimates of direct radiative forcing by aerosols have generally relied on surface aerosol radiative properties [e.g., IPCC, 1996; Charlson et al., 1992]. Establishing a link between column and surface measure- ments can help reduce some of the uncertainties in climate models and satellite retrieval algorithms that assume that surface aerosol measurements adequately represent column aerosol properties. Ideally, in a well-mixed boundary layer with no substantial amount of aerosols in the free troposphere or the stratosphere, $\tau_{\mathrm{a}}$ values should be equal to the surface light extinction coefficient integrated from the ground to the top of the boundary layer (with a relative humidity function included). We have shown that there are similarities between the mean, maximum, and minimum values of $\mathrm{PM}_{2.5}$ optical properties at the surface and total aerosol column optical properties in relation to changes in air mass origins. However, we would like to establish a more quantitative link between these two measurement methods. This has been done by comparing hourly averages of the surface fine particle light extinction coefficient at $550 \mathrm{~nm}\left(\sigma_{\mathrm{ep}}=\sigma_{\mathrm{sp} 550 \mathrm{~nm}}+\sigma_{\mathrm{ap}}\right)$ to $\tau_{\mathrm{a}}$ (logarithmically interpolated to $550 \mathrm{~nm}$ ) during the entire study period, during each season, and during different transport scenarios.

[38] We were able to obtain 1202 hourly averages of $\tau_{\mathrm{a}}$ from 7 July 2000 to 3 September 2001, and plotted them against hourly averages of $\sigma_{\text {ep }}$ (Figure 8a). The correlation between the two variables is moderate $\left(\mathrm{r}^{2}=0.57\right)$ (significance level of this and all of the following coefficients is $99.9 \%$ ) with a slope of $2332 \pm 59 \mathrm{~m}$, which is a rough estimate of the average boundary layer mixing depth [cf. Bergin et al., 2000]. A seasonal breakdown illustrates that 

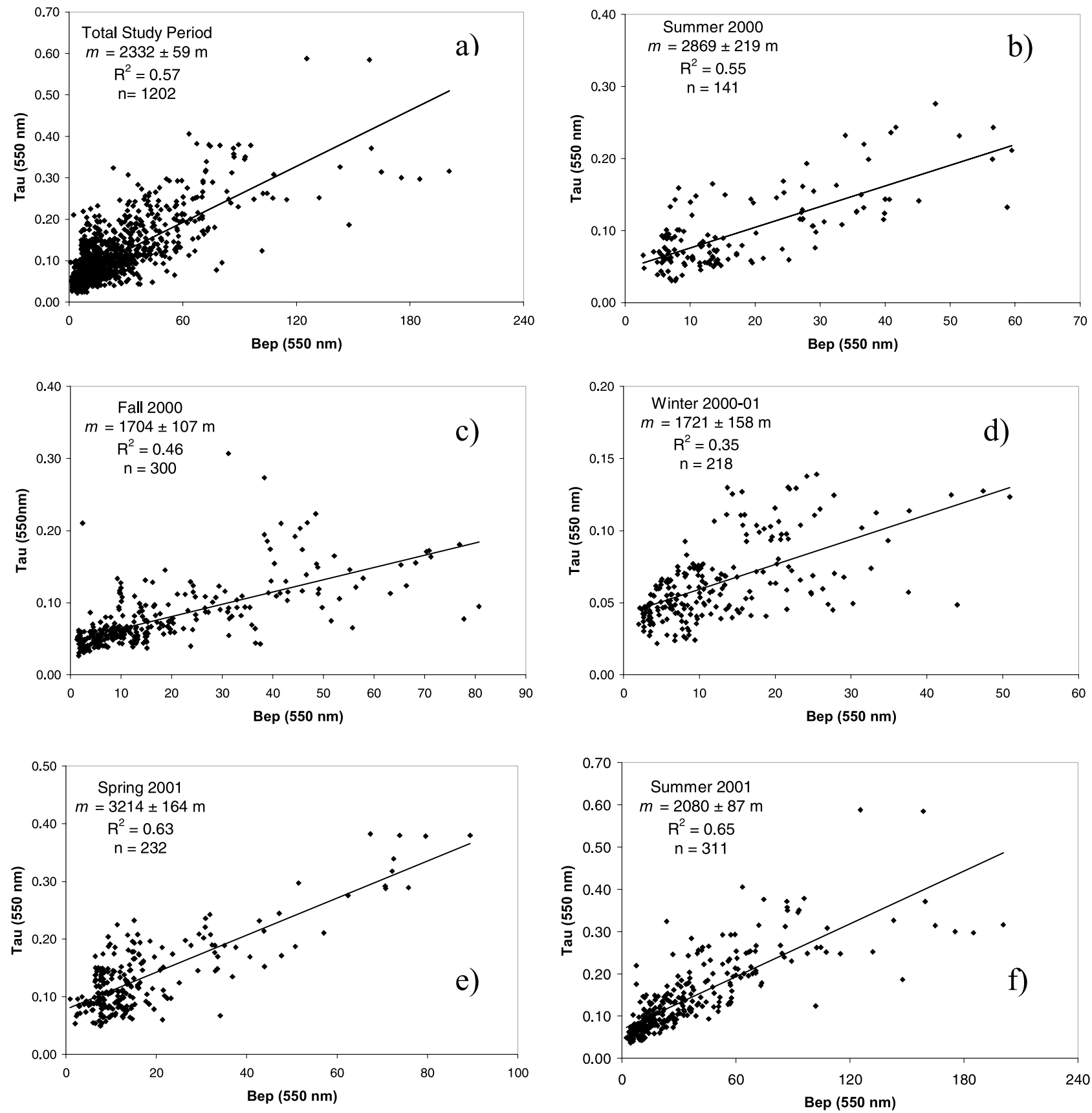

Figure 8. Total study period and seasonal breakdown of the relationship between aerosol optical depth (Tau) and surface $\mathrm{PM}_{2.5}$ light extinction coefficient (Bep; $550 \mathrm{~nm}$ ).

spring and summer 2001 also display moderate correlations $\left(\mathrm{r}^{2}=0.63\right.$ and $\mathrm{r}^{2}=0.65$, respectively), as well as summer $2000\left(\mathrm{r}^{2}=0.55\right)$, compared to winter $2000-2001$ when the two variables are poorly correlated $\left(\mathrm{r}^{2}=0.35\right)$ (Figure 8).

[39] A poor correlation between these two variables could be due to a number of factors such as (1) incomplete vertical mixing (aerosols aloft are contributing to $\tau_{\mathrm{a}}$ values and not to $\left.\sigma_{\mathrm{ep}}\right)$, (2) fluctuations in $\mathrm{RH}\left(\sigma_{\mathrm{sp}}\right.$ is measured at a low RH and $\tau_{\mathrm{a}}$ is measured at ambient $\mathrm{RH}$ ), and/or (3) differences in aerosol size distribution and/or chemical composition with height. The moderate correlation in summer is somewhat surprising given that $\mathrm{RH}$ is much more variable and normally higher at this time of year (compared to other seasons). The poor correlation during winter could be the result of a stable boundary layer due to the lack of considerable thermal updrafts. The open fields surrounding the measurement site were covered with snow from 15 December 2000 through 1 April 2001. Snow cover can cause a temperature inversion near the surface, capping any vertical movement of air [Stull, 1988]. If there is not considerable vertical mixing, a surface based measurement $\left(\sigma_{\mathrm{ep}}\right)$ and a measurement representing conditions aloft $\left(\tau_{\mathrm{a}}\right)$ would be decoupled.

[40] We have produced scatter plots of $\sigma_{\text {ep }}$ and $\tau_{\mathrm{a}}$ during the three major transport situations to examine how changes in air mass origin may influence the relationships between 

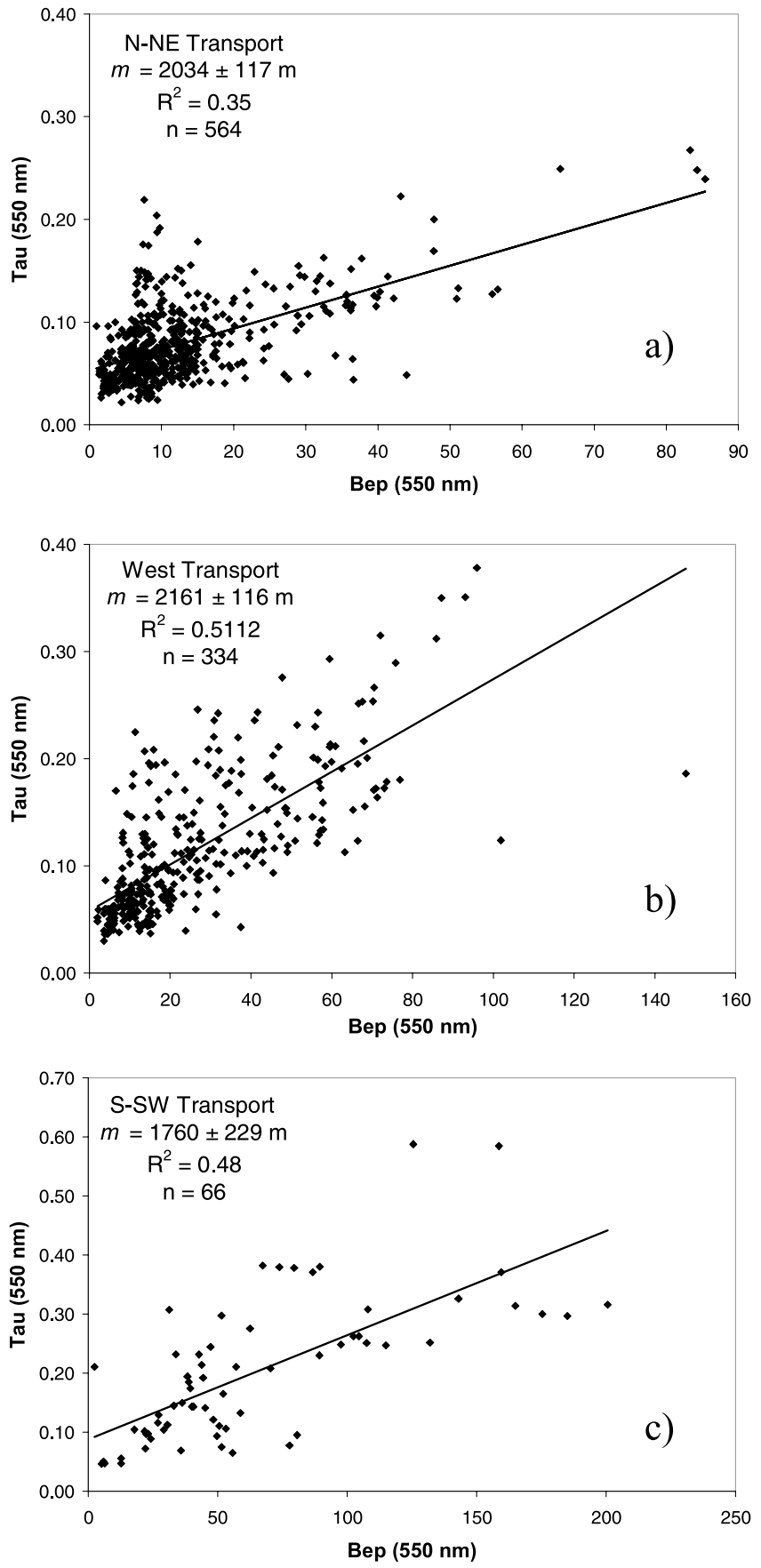

Figure 9. Scatterplots of aerosol optical depth (Tau) and the light extinction coefficient (Bep) during the three main transport situations: (a) north-northeast, (b) west, and (c) south-southwest transport.

the two variables. Because of a relatively low number of observations when $\tau_{\mathrm{a}}$ and the 6 hour trajectory interval coincided (see $\mathrm{n}$ in Table 2), we have made the assumption that transport did not change between trajectory intervals. For example, if the backward trajectories calculated at 1200 UT and 1800 UT on 1 July 2001 both originated in the west region, we assumed that the 5 hourly trajectories between these two times also originated in the west. Given the rate at which frontal systems typically move in the northeast [e.g., Brankov et al., 1998], we feel this is a reasonable assumption. This assumption increased the number of observations during north-northeast transport from 141 to 564, during west transport from 103 to 334, and during south-southwest transport from 42 to 66 (Table 2 and Figure 9)

[41] Scatter plots reveal that during times of north-northeast transport, $\sigma_{\mathrm{ep}}$ and $\tau_{\mathrm{a}}$ are poorly correlated $\left(\mathrm{r}^{2}=0.35\right)$, and are moderately correlated during west $\left(\mathrm{r}^{2}=0.51\right)$ and south-southwest $\left(\mathrm{r}^{2}=0.48\right)$ transport situations (Figure 9). A seasonal breakdown of north-northeast transport shows that the only time of year the two variables are moderately correlated is in summer 2001 (Figure 10d), a time when $\sigma_{\mathrm{ep}}$ and $\tau_{\mathrm{a}}$ values are at their highest. The moderate correlation between $\tau_{\mathrm{a}}$ and $\sigma_{\mathrm{ep}}$ seen during west transport is fairly consistent throughout the four seasons (Figures $10 \mathrm{e}-10 \mathrm{~h}$ ). Because of the low number of observations during southsouthwest transport we are not able to present a seasonal breakdown. However, the total study period scatterplot does show that a wide range of $\tau_{\mathrm{a}}$ and $\sigma_{\mathrm{ep}}$ values were observed (Figure 9c).

[42] Additionally, in each regression analysis of $\sigma_{\mathrm{ep}}$ and $\tau_{\mathrm{a}}$ in Figures 8, 9, and 10 (seasonal and transport breakdown) the Y-intercept is positive. This is likely an indication of additional aerosol loading above the surface; since $\sigma_{\mathrm{ep}}$ is measured at ground level, $\tau_{\mathrm{a}}$ measurements should be greater. This intercept could be used as a semi-quantitative measure of the relative concentration of aerosols at the surface, compared to the total column loading.

\subsection{Fine Particle Light Scattering and Absorption Efficiencies}

[43] Chemical analysis of 150 24-hour integrated $\mathrm{PM}_{2.5}$ filters have allowed us to determine the scattering efficiency $\left(\phi_{\mathrm{sp}}\right)$ and the absorption efficiency $\left(\phi_{\mathrm{ap}}\right)$ of key chemical components during the entire study period, as well as within the three different air mass types. Ion chromatography (IC) results show that $\mathrm{SO}_{4}^{2-}$ is nearly completely neutralized by $\mathrm{NH}_{4}^{+}$; linear regression (in equivalents) indicates that $\left[\mathrm{SO}_{4}^{2-}\right]=1.07 \pm 0.10\left[\mathrm{NH}_{4}^{+}\right]$with an $\mathrm{r}^{2}=0.89$. Thus for the multiple linear regression (MLR) analysis we have assumed that all sulfate is in the form of $\left(\mathrm{NH}_{4}\right)_{2} \mathrm{SO}_{4}$. Other IC results show that $\left[\mathrm{NO}_{3}^{-}\right]$is more than an order of magnitude lower than $\left[\mathrm{SO}_{4}^{2-}\right]$, therefore we have not included any $\mathrm{NO}_{3}^{-}$in the MLR analysis. Further, other ionic species measured $\left(\mathrm{Ca}^{2+}, \mathrm{Na}^{+}, \mathrm{Mg}^{2+}, \mathrm{K}^{+}, \mathrm{Cl}^{-}\right.$, and $\left.\mathrm{C}_{2} \mathrm{O}_{4}^{2-}\right)$ were at or near the LOD of the analytical method.

[44] As a result, we have included only organic carbon (OC) and $\left(\mathrm{NH}_{4}\right)_{2} \mathrm{SO}_{4}$ in the MLR model. It is recognized that fine particle mineral dust could be contributing to the measured $\sigma_{\mathrm{sp}}$ at this site; however, at other $\mathrm{PM}_{2.5}$ monitoring locations in rural New England dust concentrations are at most $10-15 \%$ of the total $\mathrm{PM}_{2.5}$ mass [e.g., Sisler and Malm, 2000; Cass et al., 1999]. This fact, coupled to the low scattering efficiency of dust $\left(\sim 1 \mathrm{~m}^{2} \mathrm{~g}^{-1}\right)$, led to the assumption that $\mathrm{OC}$ and $\left(\mathrm{NH}_{4}\right)_{2} \mathrm{SO}_{4}$ were the only major chemical species contributing to light scattering at the site. Elemental carbon (EC) is assumed to be the only chemical component responsible for fine particle light absorption.

[45] The study period $\left(\mathrm{NH}_{4}\right)_{2} \mathrm{SO}_{4} \phi_{\mathrm{sp}}$ value of $6.54 \pm$ $0.26 \mathrm{~m}^{2} \mathrm{~g}^{-1}$ (Table 3) is identical to the average $\phi_{\mathrm{sp}}$ presented by White [1990] in a literature survey of light 

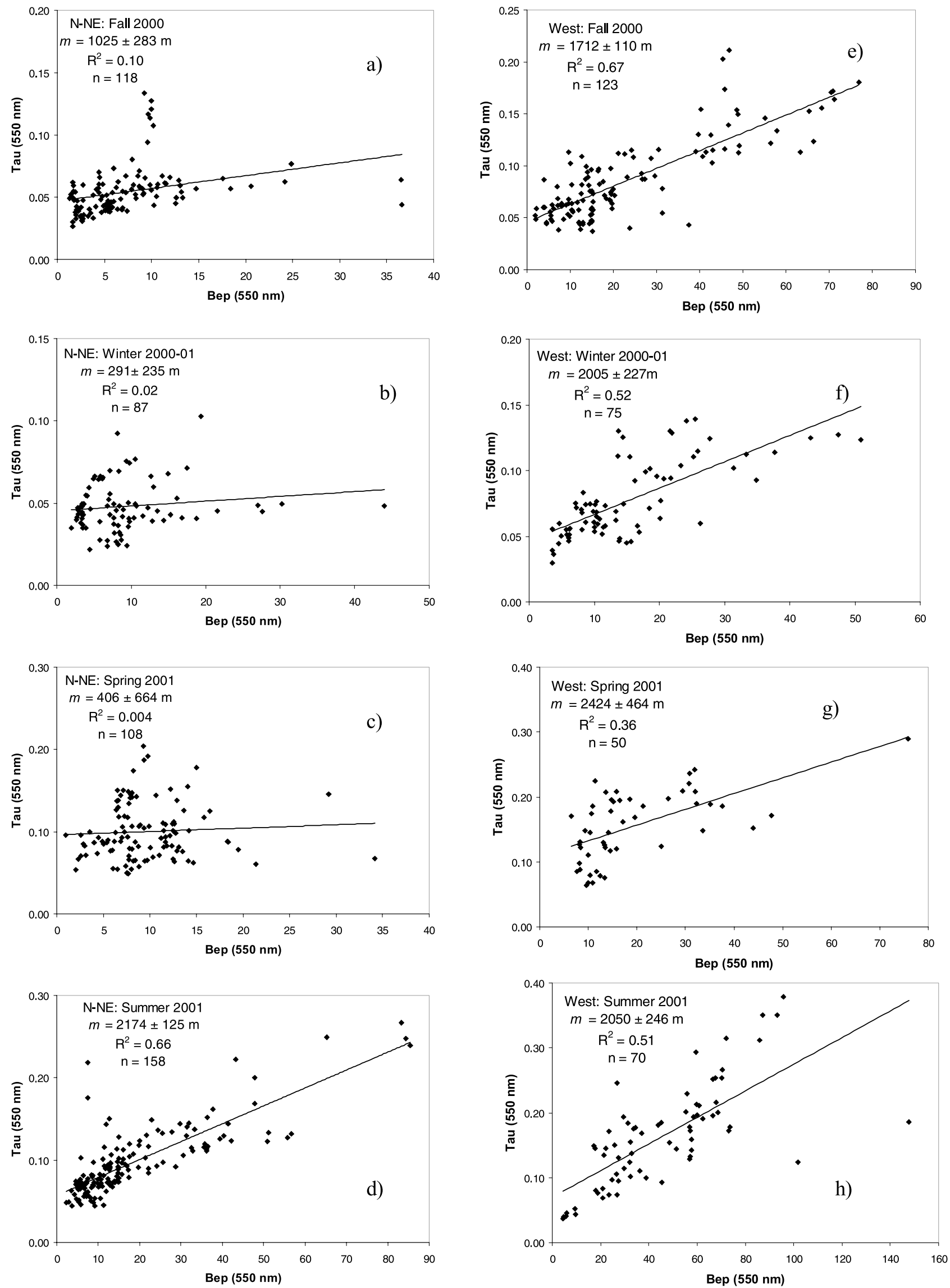

Figure 10. Seasonal distribution of the relationship between aerosol optical depth (Tau) and the light extinction coefficient $(\mathrm{Bep})(\mathrm{a}-\mathrm{d})$ during north-northeast transport and $(\mathrm{e}-\mathrm{h})$ during west transport. 
Table 3. Scattering Efficiency of Ammonium Sulfate and Organic Carbon $^{\text {a }}$

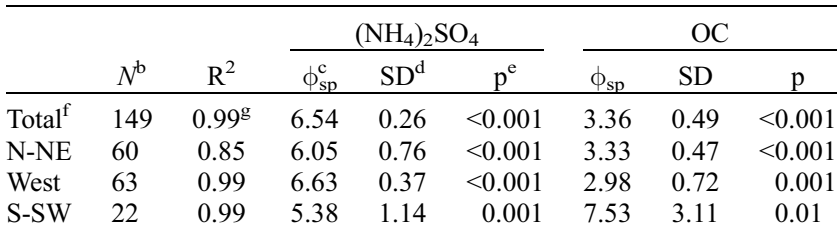

${ }^{\text {a }}$ Scattering efficiency is $\mathrm{RH} \leq 45 \%$.

${ }^{b}$ Number of 24-hour average optical and chemical measurements used in regression analysis.

${ }^{\mathrm{c}}$ Scattering Efficiency in $\mathrm{m}^{2} \mathrm{~g}^{-1}$ at $530 \mathrm{~nm}$.

${ }^{\mathrm{d}} \mathrm{SD}$, standard deviation.

${ }^{\mathrm{e}}$ Level of significance based on $t$ probability distribution.

Includes four cases when transport was from the east.

${ }^{\mathrm{g}}$ Coefficient of determination of MLR.

extinction by fine particles in the northeastern United States, and within the uncertainty of the value of $5.0 \pm 2.0 \mathrm{~m}^{2} \mathrm{~g}^{-1}$ presented by Charlson et al. [1992, 1991] and used extensively in global aerosol chemical/radiation models. The value is also similar to the $\left(\mathrm{NH}_{4}\right)_{2} \mathrm{SO}_{4} \phi_{\mathrm{sp}}$ values of $5.35 \pm$ $0.42 \mathrm{~m}^{2} \mathrm{~g}^{-1}$ and $4.94 \pm 0.68 \mathrm{~m}^{2} \mathrm{~g}^{-1}$ reported by Slater et al. [2002] for clean and polluted air masses, respectively, transported to a rural site in northern New Hampshire. Mie theory calculations find that a $\phi_{\mathrm{sp}}$ value of $6.5 \mathrm{~m}^{2} \mathrm{~g}^{-1}$ for $\left(\mathrm{NH}_{4}\right)_{2} \mathrm{SO}_{4}$ corresponds to a mean particle diameter of $0.50 \mu \mathrm{m}$ [Ouimette and Flagan, 1982]. A similar mean size for $\mathrm{SO}_{4}^{2-}(0.63 \pm 0.10 \mu \mathrm{m})$ has been reported at a rural site in central MA by Lefer and Talbot [2001].

[46] The OC $\phi_{\mathrm{sp}}$ derived for the entire study period of 3.36 $\pm 0.49 \mathrm{~m}^{2} \mathrm{~g}^{-1}$ is similar to the value of $3.81 \mathrm{~m}^{2} \mathrm{~g}^{-1}$ reported by Omar et al. [1999] for a low RH $(<63 \%)$ at the rural Bondville, Illinois site (mentioned above), which was derived using the ELSIE semi-empirical light extinction model [Sloane and Wolff, 1985]. However, the mean over 14 months in southern New Hampshire $(3.36 \pm 0.49)$ is considerably higher than the value of $1.56 \pm 0.40$ for OC scattering efficiency for the clean-sector air masses arriving in northern NH [Slater et al., 2002].

[47] Charlson et al. [1999] point out that despite the lack of standardized methods for calculating $\mathrm{SO}_{4}^{2-}$ scattering efficiencies, most of the reported values at low $\mathrm{RH}$ and a wavelength of $550 \mathrm{~nm}$ fall within a range of a factor of two. The authors also state that variations in the aerosol size distribution are the dominant cause of the observed variability [Charlson et al., 1999]. We therefore anticipated that changes in air mass origin would influence the mass scattering efficiencies of both $\mathrm{OC}$ and $\left(\mathrm{NH}_{4}\right)_{2} \mathrm{SO}_{4}$. However,

Table 4. Absorption Efficiency of Elemental Carbon

\begin{tabular}{lllllc}
\hline & $N^{\mathrm{a}}$ & $\mathrm{r}^{2}$ & $\phi_{\mathrm{ap}}^{\mathrm{b}}$ & $\mathrm{SD}^{\mathrm{c}}$ & $\mathrm{p}^{\mathrm{d}}$ \\
\hline Total $^{\mathrm{e}}$ & 149 & $0.64^{\mathrm{f}}$ & 12.85 & 0.80 & $<0.001$ \\
N-NE & 60 & 0.67 & 12.43 & 1.10 & $<0.001$ \\
West & 63 & 0.67 & 15.41 & 1.36 & $<0.001$ \\
S-SW & 22 & 0.52 & 9.74 & 2.11 & $<0.001$ \\
\hline
\end{tabular}

${ }^{\mathrm{a}}$ Number of 24-hour average optical and chemical measurements used in regression analysis.

${ }^{\mathrm{b}}$ Absorption efficiency in $\mathrm{m}^{2} \mathrm{~g}^{-1}$ at $550 \mathrm{~nm}$.

${ }^{\mathrm{c}} \mathrm{SD}$, standard deviation.

${ }^{\mathrm{d}}$ Level of significance based on $t$ probability distribution.

eIncludes four cases when transport was from the east.

${ }^{\mathrm{f}}$ Correlation coefficient from linear regression.
Table 5. Clear-Sky Average Aerosol Radiative Forcing $(\Delta \mathrm{F})$ at $\lambda=550 \mathrm{~nm}$

\begin{tabular}{lccc}
\hline & $\Delta \mathrm{F}^{\mathrm{a}}$ & Variability $^{\mathrm{b}}$ & $\mathrm{n}$ \\
\hline Year (Sept. 00-Sept 01) & -5.14 & \pm 4.32 & 70 \\
Fall 00 (Sept.-Nov.) & -4.31 & \pm 2.57 & 21 \\
Winter 00-01 (Dec.-Feb.) & -0.35 & \pm 0.83 & 12 \\
Spring 01 (Mar.-May) & -4.04 & \pm 3.70 & 14 \\
Summer 01 (June-Aug.) & -9.06 & \pm 3.77 & 23 \\
\hline
\end{tabular}

${ }^{\mathrm{a}}$ Based on daily averages in $\mathrm{Wm}^{-2}$.

${ }^{\mathrm{b}}$ Variability is reported as \pm 1 standard deviation.

OC and $\left(\mathrm{NH}_{4}\right)_{2} \mathrm{SO}_{4} \phi$ sp values are not statistically different between the three air mass source regions (Table 3), except for OC $\phi_{\mathrm{sp}}$ during days of south-southwest transport. The large standard deviation of $\mathrm{OC} \phi_{\mathrm{sp}}$ during south-southwest transport suggests that a larger data set might not yield a mean that is significantly different than the other source regions. The lack of variability of $\phi_{\mathrm{sp}}$ among different transport scenarios is consistent with the observation that $\alpha$ does not vary when air mass origins change (indicating that column size distribution is relatively stable). We conclude that even though there is a high amount of variability in the chemical composition and the amount of aerosols delivered to the site with different air mass origins, the size distribution of those particles is not significantly different (as determined by these indirect methods).

[48] Reported values of EC $\phi_{\text {ap }}$ span a much broader range (as much as an order of magnitude), as compared to the range of $\left(\mathrm{NH}_{4}\right)_{2} \mathrm{SO}_{4} \phi_{\mathrm{sp}}$ reported in the literature [e.g., Liousse et al., 1993]. Along with variations in particle size distributions (mentioned above), the variability of $\mathrm{EC} \phi_{\mathrm{ap}}$ can be attributed to (1) the lack of a universal method for measuring EC, (2) variable aerosol mixing state (i.e., internal versus external mixing), (3) the age of the aerosols (particle morphology changes), and/or (4) the enhancement of absorption by degree of aggregation [Fuller et al., 1999; Horvath, 1993]. It is likely that one or more of these factors are affecting $\phi_{\text {ap }}$ between transport from the south-southwest days $\left(\phi_{\mathrm{ap}}=9.74 \pm 2.11 \mathrm{~m}^{2} \mathrm{~g}^{-1}\right)$ and days when transport was from the west $\left(\phi_{\mathrm{ap}}=15.41 \pm 1.36 \mathrm{~m}^{2} \mathrm{~g}^{-1}\right)$ (Table 4).

\subsection{Estimating Direct Aerosol Radiative Forcing}

[49] Russell et al. [1997] have shown that aerosol layers occurring off the U.S. east coast that have $\tau_{\mathrm{a}}$ values of 0.1 to 0.5 can result in a direct aerosol forcing at the top of the atmosphere of -14 to $-48 \mathrm{Wm}^{-2}$, which is much larger than the global mean of -0.07 to $-1.24 \mathrm{Wm}^{-2}$ mentioned above. However, that study was confined to a 1-month period in July 1996. To explore seasonal and annual affects of aerosols on the regional radiative budget, we have estimated direct aerosol radiative forcing during our 14-month study period. Because equation 7 assumes that some parameters (e.g., upscatter fraction) are averaged over all solar zenith angles, we have limited radiative forcing calculations to days when there were very few clouds during the entire day, which amounted to only 82 days during the entire study period. However, during each month of our study period clear-skies existed (an average of 4 days/month).

[50] During summer 2001 a substantial average negative forcing of $-9.06 \pm 3.77 \mathrm{Wm}^{-2}( \pm 1 \sigma)$ was derived (Table 5). The highest value of $\Delta \mathrm{F}\left(-20.5 \pm 4.5 \mathrm{Wm}^{-2}\right)$ was recorded 


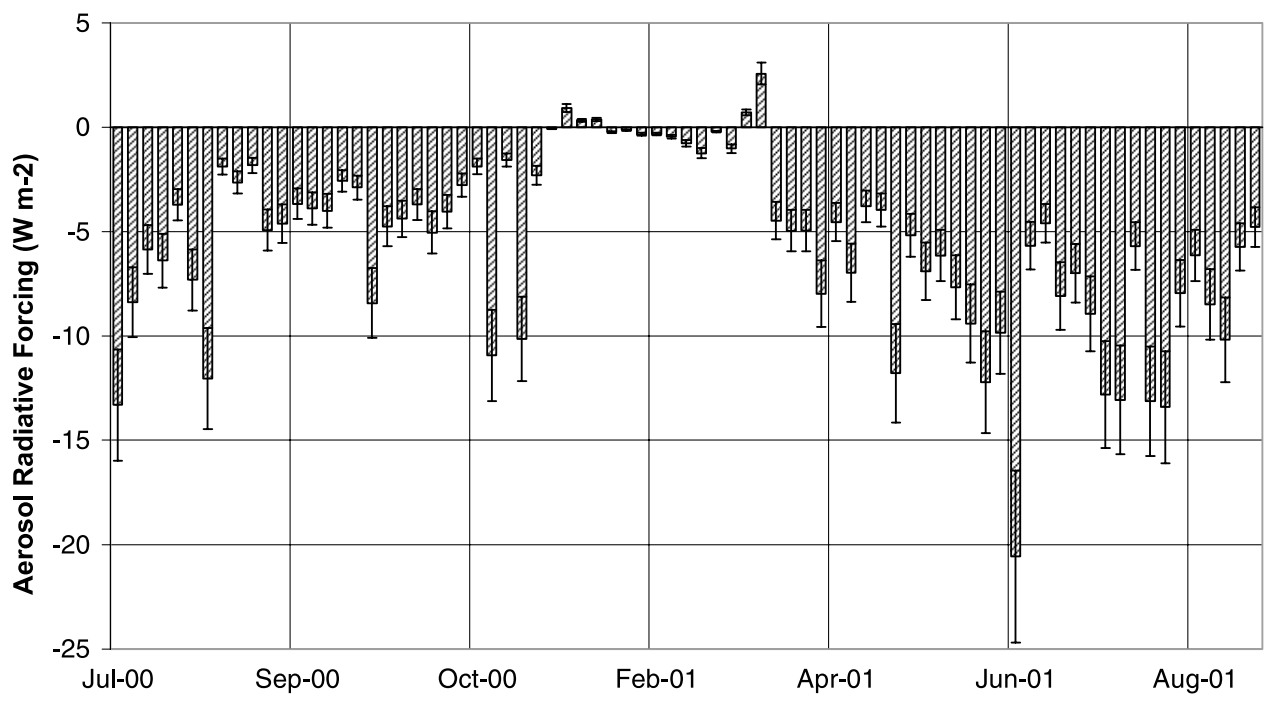

Figure 11. Clear-sky direct aerosol radiative forcing at Thompson Farm. The time series contains 82 daily averages spread over the 14-month period (gaps in the record are not shown). Error bars represent the combined standard uncertainty, which includes all instrument measurement uncertainty, as well as the result of using upper and lower limits for the upscatter fraction (0.24 to 0.27$)$.

on 27 June 2001 (Figure 11). On this day, $\tau_{\mathrm{a}}$ was above average $(0.198)$ and the single scatter albedo was the highest daytime value recorded during the entire study (0.93). Chemical mass balance of $\mathrm{PM}_{2.5}$ on 27 June indicates that $\left(\mathrm{NH}_{4}\right)_{2} \mathrm{SO}_{4}$ accounted for $\sim 60 \%$ of the aerosol mass, OC accounted for $\sim 25 \%$, and EC less than $1 \%$, helping to explain the high single scatter albedo. During winter $2000-$ 2001 an average forcing of $-0.35 \pm 0.83 \mathrm{Wm}^{-2}$ was calculated (Table 5). This relatively low radiative forcing was caused by a combination of high $R_{s}$ (due to a continuous snow cover from early-December 2000, to mid-March, 2001) and low single scatter albedo (winter average $\omega=$ 0.84; Figure 5c). During fall 2000 an average negative forcing of $-4.31 \pm 2.57 \mathrm{Wm}^{-2}$ was derived (Table 5), despite the low $\omega$ observed for that season $(\omega=0.82$, Figure $5 \mathrm{c}$ ). The fall maximum daily radiative forcing $\left(-10.9 \pm 2.3 \mathrm{Wm}^{-2}\right)$ was observed on 25 October 2000. This day was part of a 10-day regional pollution event recorded at rural, urban, and remote sites throughout New England that brought polluted air masses into the region from the west and southwest (J. F. Slater et al., Synoptic- and micro-scale meteorological controls on PM2.5, ozone, and carbon monoxide concentrations in rural New England: A case study, submitted to Journal of the Air and Waste Management Association, 2003). Similar to fall 2000 , the spring 2001 mean $\Delta \mathrm{F}$ was $-4.04 \pm 3.70 \mathrm{Wm}^{-2}$, with values exceeding $10 \mathrm{Wm}^{-2}$ on just two occasions (Figure 11 and Table 5). The annual average $\Delta \mathrm{F}$ (September 2000 -September 2001) of $-5.14 \pm 4.32 \mathrm{Wm}^{-2}$ is substantially higher than the range of estimates for the global mean mentioned above. This result is not surprising, however, given that the northeastern United States is much more industrialized than many other parts of the world.

\section{Summary and Conclusions}

[51] We have reported on a 14-month long study of the physical, chemical, and optical properties of $\mathrm{PM}_{2.5}$ at the surface, and the physical and radiative properties of the vertical column total aerosol, at a rural site in southern New Hampshire. The main conclusions that can be drawn from this work are as follows:

[52] 1. Air mass transport to the site was dominated by flow from the north-northeast and the west during 7 July 2000 to 3 September 2001, as well as during each season within this time frame.

[53] 2. Maximum values of $\tau_{a}$ were observed during summer 2001 and minimum values seen during winter 2000-2001. Minimum values of $\alpha$ in spring suggest an influence of dust aerosols aloft. $\mathrm{PM}_{2.5} \sigma_{\mathrm{sp}}$ peaked in summer 2001, with little variation in the other seasons, while $\mathrm{PM}_{2.5} \sigma_{\text {ap }}$ maximum values were seen in winter. The single scatter albedo of $\mathrm{PM}_{2.5}$ attained its lowest value of 0.81 in fall 2000 and highest value of 0.89 in summer 2001 .

[54] 3. $\mathrm{PM}_{2.5}\left[\mathrm{NH}_{4}^{+}\right],\left[\mathrm{SO}_{4}^{2-}\right], \sigma_{\mathrm{sp}}, \sigma_{\mathrm{ap}}$, and total aerosol $\tau_{\mathrm{a}}$ were highest during times of transport from the southsouthwest and lowest during north-northeast transport. The single scatter albedo was lowest during time of transport from the cleanest sector, suggesting that EC is a ubiquitous component of fine particles in New England.

[55] 4. The Angström Exponent was not significantly different between the different air mass classes indicating that the aerosol size distribution above the site is not strongly influenced by regionally distinct processes upwind.

[56] 5. $\mathbf{P M}_{2.5} \sigma_{\mathrm{ep}}$ and $\tau_{\mathrm{a}}$ were moderately correlated throughout the study period $\left(\mathrm{r}^{2}=0.57, \mathrm{n}=1202\right)$. The best correlations $\left(\mathrm{r}^{2}=0.65\right)$ occurred during summer 2001 and during transport from the west $\left(\mathrm{r}^{2}=0.51\right)$.

[57] 6. The total season mass scattering efficiency of $\left(\mathrm{NH}_{4}\right)_{2} \mathrm{SO}_{4}$ and $\mathrm{OC}$ was $6.54 \pm 0.26 \mathrm{~m}^{2} \mathrm{~g}^{-1}$ and $3.36 \pm$ $0.49 \mathrm{~m}^{2} \mathrm{~g}^{-1}$, respectively. The efficiencies for these two species were not significantly different among the three major air mass origins. The total season absorption efficiency of EC was $12.85 \pm 0.80 \mathrm{~m}^{2} \mathrm{~g}^{-1}$.

[58] 7. The yearly average $\Delta \mathrm{F}$ at the site was $-5.14 \pm$ $4.32 \mathrm{Wm}^{-2}$. In winter $\Delta \mathrm{F}=-0.35 \pm 0.83 \mathrm{Wm}^{-2}$ and in 
summer $\Delta \mathrm{F}=-9.06 \pm 3.77 \mathrm{Wm}^{-2}$, differences that can be attributed to the seasonal changes in surface albedo and fine particle single scatter albedo.

[59] This work has demonstrated that many of the physical, chemical, and optical properties of aerosols at the surface and in the vertical column are highly variable at this regional background measurement site. The fact that the derived mass scattering and absorption efficiencies do not vary significantly from theoretical values, or vary as air mass source regions changed, supports climate models and satellite retrieval algorithms that use a single geographic value for these parameters. The moderate correlation between $\sigma_{\mathrm{ep}}$ and $\tau_{\mathrm{a}}$ observed in this study suggests that vertical column aerosol radiative properties measured by surface-based radiometers only adequately represent boundary layer aerosol properties. Aerosol optical depth measurements should be supplemented by boundary layer measurements of aerosol chemical, physical, and radiative properties to help understand the mechanisms contributing to global aerosol variability.

[60] Acknowledgments. John Slater was supported by the National Aeronautics and Space Administration Headquarters under the Earth System Science Fellowship Program (grant NGT5-30349). Additional funding for equipment and filter analysis was provided by the AIRMAP Program at UNH, which is sponsored by the National Oceanic and Atmospheric Administration (grant NA97RP0309). We also acknowledge the anonymous reviewers of this work whose comments greatly improved the manuscript.

\section{References}

Ahern, F. J., R. P. Gauthier, P. M. Teillet, J. Sirois, G. Fedosejevs, and D. Lorente (1991), Investigation of continental aerosols with highspectral-resolution solar-extinction measurements, Appl. Opt., 30 , 5276-5287.

Anderson, T. L., et al. (1996), Performance characteristics of a highsensitivity, three-wavelength, total scatter/backscatter nephelometer, J. Atmos. Oceanic Technol., 13, 967-986.

Anderson, T. L., D. S. Covert, J. D. Wheeler, J. M. Harris, K. D. Perry, B. E. Trost, D. J. Jaffe, and J. A. Ogren (1999), Aerosols backscatter fraction and single scatter albedo: Measured values and uncertainties at a coastal station in the Pacific Northwest, J. Geophys. Res., 104, 26,793-26,807.

Ångström, A. (1929), On the atmospheric transmission of sun radiation and on dust in the air, Geogr. Ann., 2, 35-42.

Angström, A. (1930), On the atmospheric transmission of sun radiation, Geogr. Ann., 2-3, 78-86.

Arnott, W. P., H. Moosmüller, P. J. Sheridan, J. A. Ogren, R. Raspet, W. V. Slaton, J. L. Hand, S. M. Kreidenweis, and J. L. Collett Jr. (2003), Photoacoustic and filter-based ambient aerosol light absorption measurements: Instrument comparisons and the role of relative humidity, J. Geophys. Res., 108(D1), 4034, doi:10.1029/2002JD002165.

Bates, T. S., B. J. Huebert, J. L. Gras, F. B. Griffiths, and P. A. Durkee (1998), International Global Atmospheric Chemistry (IGAC) project's first Aerosol Characterization Experiment (ACE 1), Overview, J. Geophys. Res., 103, 16,297-16,318.

Bergin, M. H., S. E. Schwartz, R. N. Halthore, J. A. Ogren, and D. L. Hlavka (2000), Comparison of aerosol optical depth inferred from surface measurements with that determined by sun photometry for cloud-free conditions at a continental U.S. site, J. Geophys. Res., 105, 6807-6816.

Birch, M. E., and R. A. Cary (1996), Elemental carbon-based method for monitoring occupational exposures to particulate diesel exhaust, Aerosol Sci. Technol., 25, 221-241.

Bokoye, P., N. T. O’Neill, and A. Royer (1998), AEROCAN 1998 status report, 74 pp., Cent. d'Appl. et de Rech. en Teledetection, Univ. de Sherbrooke, Quebec, Canada.

Bond, T. C., T. L. Anderson, and D. Campbell (1999), Calibration and intercomparison of filter-based measurements of visible light absorption by aerosols, Aerosol Sci. Technol., 30, 582-600.

Brankov, E., S. T. Rao, and P. S. Porter (1998), A trajectory-clusteringcorrelation methodology for examining the long-range transport of air pollutants, Atmos. Environ., 32, 1525-1534.
Cass, G. R., L. G. Salmon, D. U. Pedersen, J. L. Durant, R. Bigg, A. Lunts, and M. Utell (1999), Assessment of concentrations and chemical composition of fine and coarse particles in the northeastern United States, p. 77, Northeast States for Coord. Air Use Manage., Boston, Mass.

Charlson, R. J., and J. Heintzenberg (1995), Aerosol Forcing of Climate, 416 pp., John Wiley, Hoboken, N. J.

Charlson, R. J., J. Langner, H. Rodhe, C. B. Leovy, and S. G. Warren (1991), Perturbation of the northern hemisphere radiative balance by backscattering from anthropogenic sulfate aerosols, Tellus, Ser. AB, 43, $152-163$.

Charlson, R. J., S. E. Schwartz, J. M. Hales, R. D. Cess, J. A. Coakley, J. E. Hansen, and D. J. Hofmann (1992), Climate forcing by anthropogenic aerosols, Science, 255, 423-430.

Charlson, R. J., T. L. Anderson, and H. Rodhe (1999), Direct climate forcing by anthropogenic aerosols: Quantifying the link between atmospheric sulfate and radiation, Contrib. Atmos. Phys., 72, 79-94.

Chýlek, P., and J. A. Coakley (1974), Aerosols and climate, Science, 183, $75-77$.

Chýlek, P., and J. Wong (1995), Effect of absorbing aerosols on global radiation budget, Geophys. Res. Lett., 22, 929-931.

Delene, D. J., and J. A. Ogren (2001), Variability of aerosol optical properties at four North American surface monitoring sites, J. Atmos. Sci., 34, $376-385$

Dentener, F. J., G. R. Carmichael, Y. Zhang, J. Lelieveld, and P. J. Crutzen (1996), Role of mineral aerosol as a reactive surface in the global troposphere, J. Geophys. Res., 101, 22,869-22,889.

Draxler, R. R., and G. D. Hess (1997), Description of the HYSPLIT 4 modeling system, NOAA Tech. Mem. ERL ARL-224, pp. 1-24, Natl. Oceanic and Atmos. Admin., Silver Spring, Md.

Eatough, D. J., F. Obeidi, Y. Pang, Y. Ding, N. L. Eatough, and W. E. Wilson (1999), Integrated and real-time diffusion denuder sampler for $\mathrm{PM}_{2.5}$, Atmos. Environ., 33, 2835-2844.

Fuller, K. A., W. C. Malm, and S. M. Kreidenweis (1999), Effects of mixing on extinction by carbonaceous particles, J. Geophys. Res., 104, $15,941-15,954$

Goldberg, E. D. (1985), Black Carbon in the Environment, 89 pp., John Wiley, N. J.

Grant, K. E., C. C. Chuang, A. S. Grossman, and J. E. Penner (1999), Modeling the spectral optical properties of ammonium sulfate and biomass aerosols: Parameterization of relative humidity effects and model results, Atmos. Environ., 33, 2603-2620.

Gray, H. A., G. R. Cass, J. J. Huntzicker, E. K. Heyerdahl, and J. A. Rau (1986), Characteristics of atmospheric organic and elemental carbon particle concentration in Los Angeles, Environ. Sci. Technol., 20, 580589

Hansen, J., and P. Travis (1974), Light scattering in planetary atmospheres, Space Sci. Rev., 16, 527-610.

Harrison, L., and J. Michalsky (1994), Objective algorithms for the retrieval of optical depths from ground-based measurements, Appl. Opt., 33, $5126-5132$

Harrison, L., J. Michalsky, and J. Berndt (1994), Automated multifilter rotating shadow-band radiometer: An instrument for optical depth and radiation measurements, Appl. Opt., 33, 5118-5125.

Haywood, J. M., and K. P. Shine (1995), The effect of anthropogenic sulfate and soot aerosol on the clear sky planetary radiation budget, Geophys. Res. Lett., 22, 603-606.

Hegg, D. (1993), A theoretical study of the effect of relative humidity on light scattering by tropospheric aerosols, J. Geophys. Res., 98, 18,43518,439 .

Hegg, D. A., J. Liningston, P. V. Hobbs, T. Novakov, and P. Russell (1997), Chemical apportionment of aerosol column optical depth off the midAtlantic coast of the United States, J. Geophys. Res., 102, 25,29325,303 .

Heintzenberg, J., R. J. Charlson, A. D. Clarke, C. Liousse, V. Ramaswamy, K. P. Shine, M. Wendisch, and G. Helas (1997), Measurements and modeling of aerosols single-scattering albedo: Progress, problems, and prospects, Beitr. Phys. Atmos., 70, 249-263.

Holben, B. N., et al. (2001), An emerging ground-based aerosols climatology: Aerosol optical depth from AERONET, J. Geophys. Res., 106, $12,067-12,097$.

Horvath, H. (1993), Atmospheric light absorption-A review, Atmos. Environ., Part A, 27, 293-317.

Ingold, T., C. Matzler, N. Kampfer, and A. Heimo (2001), Aerosol optical depth measurements by means of a sun photometer network in Switzerland, J. Geophys. Res., 106, 27,537-27,554.

IPCC (1996), Climate Change 1995, Radiative Forcing of Climate Change, edited by J. T. Houghton, L. G. Meira, and J. Bruce, pp. 457-489, Cambridge Univ. Press, New York.

IPCC (2001), Climate Change 2001: The Scientific Basis; Contribution of the Working Group I to the Third Assessment Report of the Intergovern- 
mental Panel on Climate Change, edited by J. T. Houghton, Y. Ding, and D. J. Griggs, pp. 289-348, Cambridge Univ. Press, New York.

Jordan, C. E., R. W. Talbot, and B. D. Keim (2000), Water-soluble nitrogen at the New Hampshire sea coast: $\mathrm{HNO}_{3}$, aerosols, precipitation, and fog, J. Geophys. Res., 105, 26,403-26,431.

Kasten, F. (1966), A new table and approximate formula for relative optical air mass, Arch. Meteorol. Geophys. Bioklimatol., Ser. B, 14, 206-223.

Kaufman, Y. J., D. Tanré, H. R. Gordon, T. Nakajima, J. Lenoble, R. Frouin, H. Grassl, B. M. Herman, M. D. King, and P. M. Teillet (1997), Passive remote sensing of tropospheric aerosol and atmospheric correction for the aerosol effect, J. Geophys. Res., 102, 16,815-16,830.

Kaufman, Y. J., et al. (1998), Smoke, clouds, and radiation-Brazil (SCAR-B) experiment, J. Geophys. Res., 103, 31,783-31,808.

King, M. D., Y. J. Kaufman, W. P. Menzel, and D. Tanré (1992), Remote sensing of cloud, aerosol, and water vapor properties fro the Moderate Resolution Imaging Spectrometer (MODIS), IEEE Trans. Geosci. Remote Sens., 30, 2-27.

King, M. D., Y. J. Kaufman, D. Tanré, and T. Nakajima (1999), Remote sensing of tropospheric aerosols from space: Past, present, and future, Bull. Am. Meteorol. Soc., 80, 2229-2259.

Koloutsou-Vakakis, S., C. M. Carrico, P. Kus, M. J. Rood, Z. Li, R. Shrestha, J. A. Ogren, J. C. Chow, and J. G. Watson (2001), Aerosol properties at a midlatitude Northern Hemisphere continental site, J. Geophys. Res., 106, 3019-3032.

Lefer, B. L., and R. W. Talbot (2001), Summertime measurements of aerosol nitrate and ammonium at a northeastern U.S. site, J. Geophys. Res., 106, 20,365-20,378

Liousse, C., H. Cachier, and S. G. Jennings (1993), Optical and thermal measurements of black carbon aerosol content in different environments: Variations of the specific attenuation cross-section, Atmos. Environ., Part A, 27, 1203-1211.

Lucht, W., C. B. Schaaf, and A. H. Strahler (2000), An algorithm for the retrieval of albedo from space using semiemprical BRDF models, IEEE Trans. Geosci. Remote Sens., 38, 977-998.

Malm, W. C. (2000), Spatial and seasonal patterns and temporal variability of haze and its constituents in the United States: Report III, Coop. Inst for Res. in the Atmos., Colo. State Univ., Fort Colllins.

Malm, W. C., and D. E. Day (2001), Estimates of aerosol species scattering characteristics as a function of relative humidity, Atmos. Environ., 35, $2845-2860$

Malm, W. C., and S. M. Kreidenweis (1997), The effects of models of aerosol hygroscopicity on the apportionment of extinction, Atmos. Environ., 31, $1965-1976$

Malm, W. C., J. F. Sisler, D. Huffman, R. A. Eldred, and T. A. Cahill (1994), Spatial and seasonal trends in particle concentration and optical extinction in the United States, J. Geophys. Res., 99, 1347-1370.

Michalsky, J. J., J. A. Schlemmer, N. R. Larson, L. C. Harrison, W. E. Berkheiser, and N. S. Laulainnen (1994), Measurements of the seasonal and annual variability of total column aerosol in a northeastern U.S network, in Aerosols and Atmospheric Optics: Radiative Balance, pp. 247-258, Air and Waste Manage. Assoc., Pittsburgh, Pa.

Michalsky, J. J., J. A. Schlemmer, W. E. Berkheiser, J. L. Berndt, L. C. Harrison, N. S. Laulainen, N. R. Larson, and J. C. Barnard (2001), Multiyear measurements of aerosols optical depth in the Atmospheric Radiation Measurement and Quantitative Links program, J. Geophys. Res., 106, 12,099-12,107.

NOAA-CMDL (1998), Climate Monitoring and Diagnostics Laboratory, Summary Rep. 24: 1996-1997, pp. 52-75, Natl. Oceanic and Atmos Admin., Boulder Colo.

NOAA-CMDL (2001), Climate Monitoring and Diagnostics Laboratory, Summary Rep. 25: 1998-1999, pp. 47-74, Natl. Oceanic and Atmos. Admin., Boulder Colo.

Novakov, T., D. A. Hegg, and P. V. Hobbs (1997), Airborne measurements of carbonaceous aerosols on the east coast of the United States, J. Geophys. Res., 102, 30,023-30,030.

Ogren, J. A., and R. J. Charlson (1983), Elemental carbon in the atmosphere: Cycle and lifetime, Tellus, Ser. B, 35, 241-254.

Omar, A. H., S. Biegalski, S. M. Larson, and S. Landsberger (1999), Particulate contributions to light extinction and local forcing at a rural Illinois site, Atmos. Environ., 33, 2637-2646.

Ouimette, J. R., and R. C. Flagan (1982), The extinction coefficient of multicomponent aerosols, Atmos. Environ., 16, 2405-2419.

Penner, J. E., R. J. Charlson, J. M. Hales, N. S. Laulainen, R. Leifer, T. Novakov, J. Ogren, L. F. Radke, S. E. Schwartz, and L. Travis (1994), Quantifying and minimizing uncertainty of climate forcing by anthropogenic aerosols, Bull. Am. Meteorol. Soc., 75, 375-400.

Penner, J. E., C. C. Chuang, and K. Grant (1998), Climate forcing by carbonaceous and sulfate aerosols, Clim. Dyn., 32, 839-851.
Ramanathan, V., et al. (2001), Indian Ocean Experiment: An integrated analysis of the climate forcing and effects of the great Indo-Asian haze, J. Geophys. Res., 106, 28,410-28,426.

Rogge, W. F., M. A. Mazurek, L. M. Hildemann, and G. R. Cass (1993), Quantification of urban organic aerosols at a molecular level: Identification, abundance and seasonal variation, Atmos. Environ., Part A, 27, $1309-1330$.

Russell, P., and J. Heintzenberg (2000), An overview of the ACE 2 Clear Sky Column Closure Experiment (Clearcolumn), Tellus, 54, Ser. B, 462482.

Russell, P. B., S. A. Kinne, and R. W. Bergstrom (1997), Aerosol climate effects: Local radiative forcing and column closure experiments, J. Geophys. Res., 102, 9397-9407.

Russell, P. B., P. V. Hobbs, and L. L. Stowe (1999), Aerosol properties and radiative effect in the United States East Coast haze plume: An overview of the Tropospheric Aerosol Radiative Forcing Observational Experiment (TARFOX), J. Geophys. Res., 104, 2213-2222.

Schauer, J. J., W. F. Rogge, L. M. Hildemann, M. A. Mazurek, G. R. Cass, and B. R. T. Simoneit (1996), Source apportionment of airborne particulate matter using organic compounds as tracers, Atmos. Environ., 30, $3837-3855$.

Schwartz, S. E., and M. O. Andreae (1996), Uncertainty in climate change caused by aerosols, Science, 272, 1121-1122.

Shaw, G. E. (1976), Error analysis of multi-wavelength sun photometry, Pure Appl. Geophys., 114, 1-14.

Shaw, G. E. (1983), Sun photometry, Bull. Am. Meteorol. Soc., 64, 4-10. Sheridan, P. J., and J. A. Ogren (1999), Observations of the vertical and regional variability of aerosol optical properties over central and eastern North America, J. Geophys. Res., 104, 16,793-16,805.

Sisler, J. F., and W. C. Malm (2000), Interpretation of trends of PM2.5 and reconstructed visibility from the IMPROVE network, J. Air Waste Manage. Assoc., 50, 775-785.

Slater, J. F., J. E. Dibb, B. D. Keim, and R. W. Talbot (2002), Light extinction by fine atmospheric particles in the White Mountains region of New Hampshire and its relationship to air mass transport, Sci. Total Environ., 287, 221-239.

Sloane, C. S. (1986), Effect of composition on aerosol light scattering efficiencies, Atmos. Environ., 20, 1025-1037.

Sloane, C. S., and G. T. Wolff (1985), Prediction of ambient light scattering using a physical model responsive to relative humidity: Validation with measurements from Detroit, Atmos. Environ., 19, 669-680.

Smirnov, A., A. Royer, N. T. O'Neill, and A. Tarussov (1994), A study of the link between synoptic air mass type an atmospheric optical parameters, J. Geophys. Res., 99, 20,967-20,982.

Stull, R. B. (1988), An Introduction to Boundary Layer Meteorology, pp. 17-171, Kluwer Acad., Norwell, Mass.

Tanré, D., Y. J. Kaufman, M. Herman, and S. Mattoo (1997), Remote sensing of aerosols optical properties over oceans using the MODIS/ EOS spectral radiances, J. Geophys. Res., 102, 16,971-16,988.

Turpin, B. J., J. J. Huntzicker, and S. V. Hering (1994), Investigation of organic aerosol sampling artifacts in the Los Angeles basin, Atmos. Environ., 28, 3061-3071.

White, W. H. (1986), On the theoretical and empirical basis for apportioning extinction by aerosols: A critical review, Atmos. Environ., 20, 16591672 .

White, W. H. (1990), The contribution of fine particle scattering to total extinction, sections 4, 1-4.4, in Acidic Deposition State of Science and Technology Report 24, pp. 34-78, Natl. Acid Precip. Assess. Program, U.S. Gov. Print. Off., Washington, D. C.

White, W. H., and P. T. Roberts (1977), On the nature and origins of visibility-reducing aerosols in the Los Angeles air basin, Atmos. Environ., $11,803-812$

Wiscombe, W. J., and G. W. Grams (1976), The backscatter fraction in two-stream approximations, J. Atmos. Sci., 33, 2440-2451.

Wolff, G. T., R. J. Countess, P. J. Groblicki, M. A. Ferman, S. H. Cadle, and J. L. Muhlbaier (1981), Visibility-reducing species in the Denver "brown cloud"-Sources and temporal patterns, Atmos. Environ., 15, 24852502 .

J. E. Dibb, Climate Change Research Center, Institute for the Study of Earth, Oceans, and Space, Earth Science Department, University of New Hampshire, Durham, NH 03824-3525, USA.

J. F. Slater, Division of Engineering, Mathematics, and Science, Daniel Webster College, 20 University Drive, Nashua, NH 03063, USA. (jslater@dwc.edu) 